U.S. Department of the Interior

U.S. Geological Survey

\title{
SEISMIC-REFLECTION INVESTIGATIONS OF THE TEXAS SPRINGS SYNCLINE FOR GROUND WATER DEVELOPMENT, DEATH VALLEY NATIONAL PARK
}

By

Michael N. Machette, William J. Stephenson, Robert A. Williams,

Jack K. Odum, David M. Worley, and Richard L. Dart

Open-File Report 00-106

This report is preliminary and has not been reviewed for conformity with U.S. Geological Survey editorial standards nor with the North American Stratigraphic Code. Any use of trade names in this publication is for descriptive purposes only and does not imply endorsement by the U.S. Government

2000

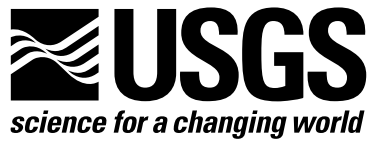




\title{
SEISMIC-REFLECTION INVESTIGATIONS OF THE TEXAS SPRINGS SYNCLINE FOR GROUND W ATER DEVELOPMENT, DEATH VALLEY NATIONAL PARK
}

\author{
by \\ Michael N. Machette, William J. Stephenson, Robert A. Williams, Jack K. Odum, \\ David M. Worley, and Richard L. Dart \\ U.S. Geological Survey \\ Geologic Hazards Team, Central Region \\ MS 966, P.O. Box 25046 \\ Golden, Colorado 80225-0046
}

Technical Report from Cooperative Agreement between the National Park Service, Death Valley National Park, and the U.S. Geological Survey, Geologic Division (Central Region)

This report is preliminary and has not been reviewed for conformity with U.S. Geological Survey editorial standards nor with the North American Stratigraphic Code. Any use of trade names in this publication is for descriptive purposes only and does not imply endorsement by the U.S. Government

March 1, 2000 


\section{SUM M ARY}

The U.S. Geological Survey has completed an integrated geologic and geophysical study of the Texas Springs syncline for the National Park Service with the intention of locating a new production water well near existing water-collection and distribution facilities. Subsurface information was required to determine which, if any, sites within the syncline would be favorable for a well. About $4.2 \mathrm{~km}$ (2.6 mi.) of high-resolution seismic-reflection data were collected across and along the Texas Springs syncline. Two of our three lines, designated DV-1 and DV-3, cross the syncline, whereas the third line (DV-2) runs parallel to the north-northwest-trending syncline axis.

Line DV-2 shows a series of prominent reflections that thicken to the southeast into the deeper part of the Texas Springs syncline. Gravels above these reflectors are probably the source aquifer for both Texas and Travertine Springs. In the area about 245-945 m (800-3,100 ft) southsoutheast of the Texas Springs monitoring well, we found a deeper southeastward-thickening sequence of reflective strata (interbedded basin-fill deposits?) that might provide a second deeper aquifer for a production well. We consider this area along the axis of the syncline to be a prime target for the National Park Service's planned production water well. In addition to this site having inferred favorable geologic and hydrologic characteristics, it has the attractive benefits of being relatively close to the existing water collection system at Texas Springs and access roads.

Although several other sites along each of the three reflection lines (and between them) may also have favorable conditions, we believe that the site south-southeast of the monitoring well is the best target identified by our geologic and geophysical studies.

\section{SCOPE OF WORK}

In anticipation of the siting and construction of a production potable water well in Death Valley National Park, the National Park Service (NPS) employed the U.S. Geological Survey (USGS) to collaborate in a subsurface imaging investigation. NPS wanted to examine the possibility of locating this production well within the "Texas Springs syncline," near existing water production and distribution facilities.

Subsurface information for the study area was required to determine further suitability of the Texas Springs syncline as a well site. Discussions between NPS and USGS staffs concluded that a high-resolution seismic-reflection survey of the study area would be a cost-effective manner of acquiring the information. The USGS has the technical expertise, trained personnel, and equipment to conduct such surveys.

Three seismic-reflection profiles were acquired. The preferred power source (i.e., input energy) for the survey was a group of three hand-operated compactors (known in the construction industry as łwackers). The wackers produce a seismic energy source appropriate for the depth of investigation for this study. Three wackers were used to simultaneously provide a semirandom input source that helps eliminate cultural and random noise. The USGS seismic-

$\ddagger$ Use of commercial names is for descriptive purposes only and does not represent a product endorsement by the U.S. Government. 
reflection crew consisted of five persons, whereas several others surveyed the elevation and lateral position of shot points. The NPS office at Cow Creek provided two maintenance workers who helped the geophysics crew and assisted in other aspects of the project.

\section{Acknow ledgements}

Ren Thompson (USGS, Denver, Colorado), Janet Slate (USGS, Denver, Colorado), and Larry Martin (NPS Water Resources Division, Fort Collins, Colorado) assisted in the surveying of vibration (shot) points for the seismic-reflection survey, as well as cultural and geographic control points. Sarah Koenig (NPS, Natural Resources Division, Death Valley) provided precise GPS location data for the $1 / 4$ section benchmark that was used for vertical control. We particularly thank Mel Essington (NPS, Natural Resources Division, Death Valley), who provided logistical support and was our liaison with the NPS staff in Death Valley National Park

\section{GEOLOGIC SETTING}

\section{Stratigraphy of the Furnace Creek basin}

The Furnace Creek basin is a late Cenozoic structural depression that developed in response to large-scale right-lateral displacement along the Furnace Creek fault and detachment faulting along the northern part of the Black Mountains during middle Miocene to Pliocene time (figure 1). The syntectonic basin fill of the Furnace Creek basin consists of the Artists Drive (ca. 14-6 Ma), Furnace Creek (ca. 6 to perhaps $3 \mathrm{Ma}$ ), and the Funeral (ca. 5 to perhaps $1 \mathrm{Ma}$ ) Formations. These time designations are from Wright and others (1999), modified from recent stratigraphic work on volcanic ashes within the upper part of the Furnace Creek Formation and the Funeral Formation by Machette (unpubl. data, 1999). Due to a lack of exposure and the deep projected depth of the Artists Drive Formation beneath the Texas Springs syncline, no further discussion of the Artist Drive Formation is included herein. However, sedimentary rocks of the Furnace Creek and Funeral Formations, (potential ground-water aquifers for the Furnace Creek Basin), are discussed below.

\section{The Furnace Creek Formation}

The Furnace Creek Formation is well exposed along its namesake-Furnace Creek Wash (figure 1). In ascending order, the sequence consists of unit A, a basal conglomerate and upward-fining section (sandstone, siltstone and basalt flows) that are exposed south of Zabriskie Point; unit B, a medial fine-grained section exposed near Zabriskie Point and south of the Furnace Creek Inn; and unit C, a upper upward-fining section (conglomerate sandstone, siltstone, and mudstone) that is exposed between Furnace Creek Inn and Texas Springs Campground. The composite stratigraphic section shown in figure 2 is based on the mapping and cross sections of McAllister (1970). The right-hand column of figure 2 is based on his cross

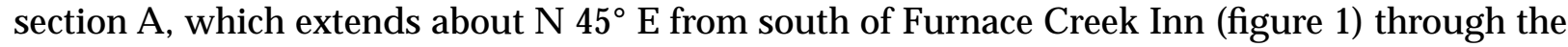
Texas Springs monitoring well. The left-hand column of figure 2 is based on his cross section B, which extends from the Artist Drive Formation (2.5 km southwest of Zabriskie Point, figure 1) along a trend of $\mathrm{N} 38^{\circ} \mathrm{E}$; it crosses Echo Canyon Road near the axis of the Texas Springs syncline. Together, McAllister's two cross sections show about 2,500 m (8,200 ft) of basin-fill sedi- 
ment, the majority of which is in the Furnace Creek Formation (Tfc). Most of the coarsegrained material within the Furnace Creek Formation was derived from the Black Mountains as evidenced by gravels that have dominant volcanic and volcanoclastic lithologies. These basic relationships described above are well displayed by McAllister's (1970) mapping, although much of the critical stratigraphy for the study area is covered by deposits of the Funeral Formation and Quaternary surficial units that consist mainly of piedmont alluvium.

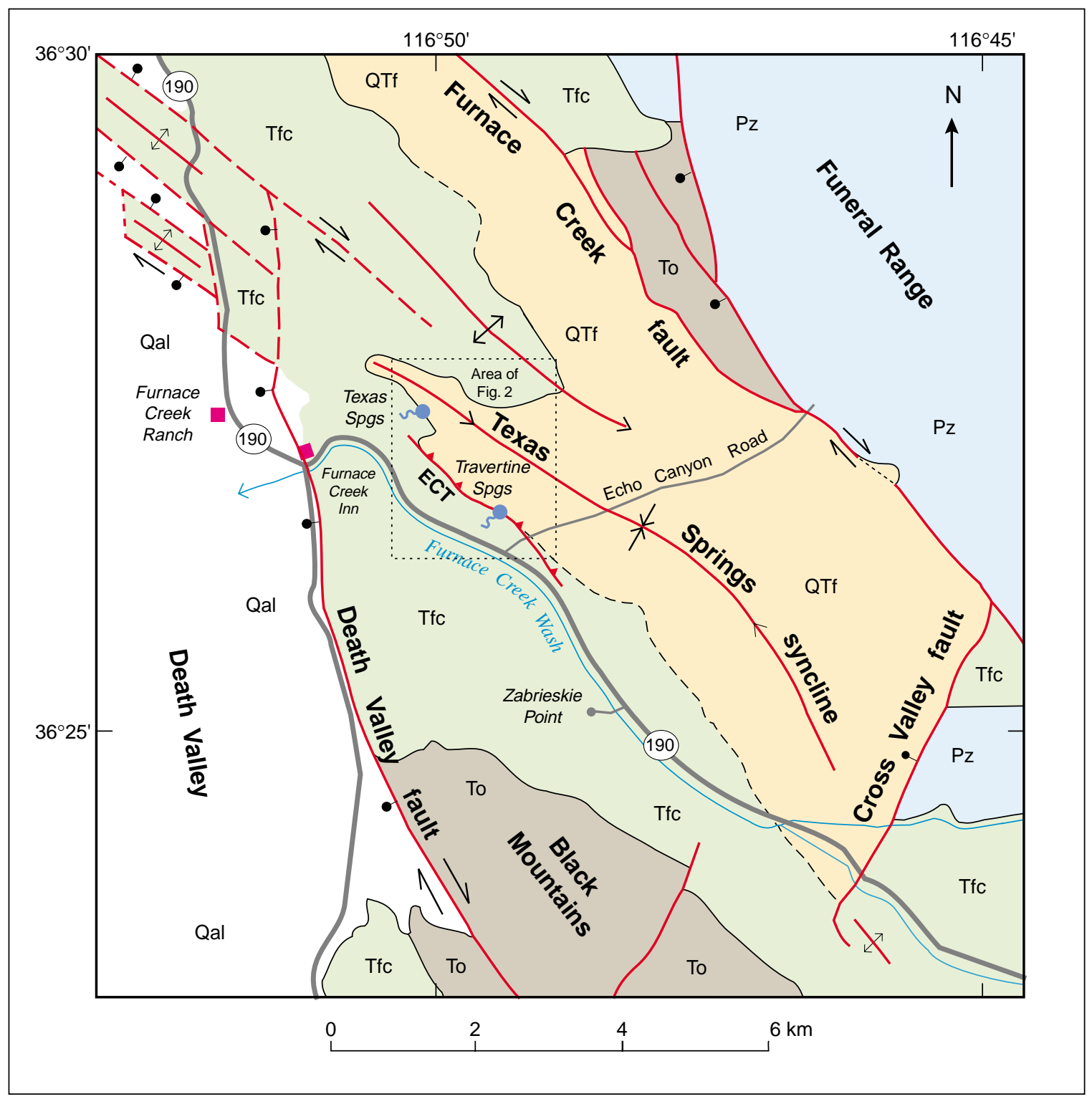

FIGURE 1. Generalize map of Furnace Creek basin showing major structural features and selected geographic and cultural features. Area of figure 3 (Texas Springs synclines) shown by dotted rectangle. Symbols: ECT, Echo Canyon thrust (fault); Qal, undivided Quaternary deposits in Death Valley (proper); QTf, Quaternary alluvium and Funeral Fm; Tfc, Furnace Creek Fm; To, older basin fill and Tertiary units; Pz, undivided Paleozoic rocks. Map derived from Hunt and Mabey (1966). 


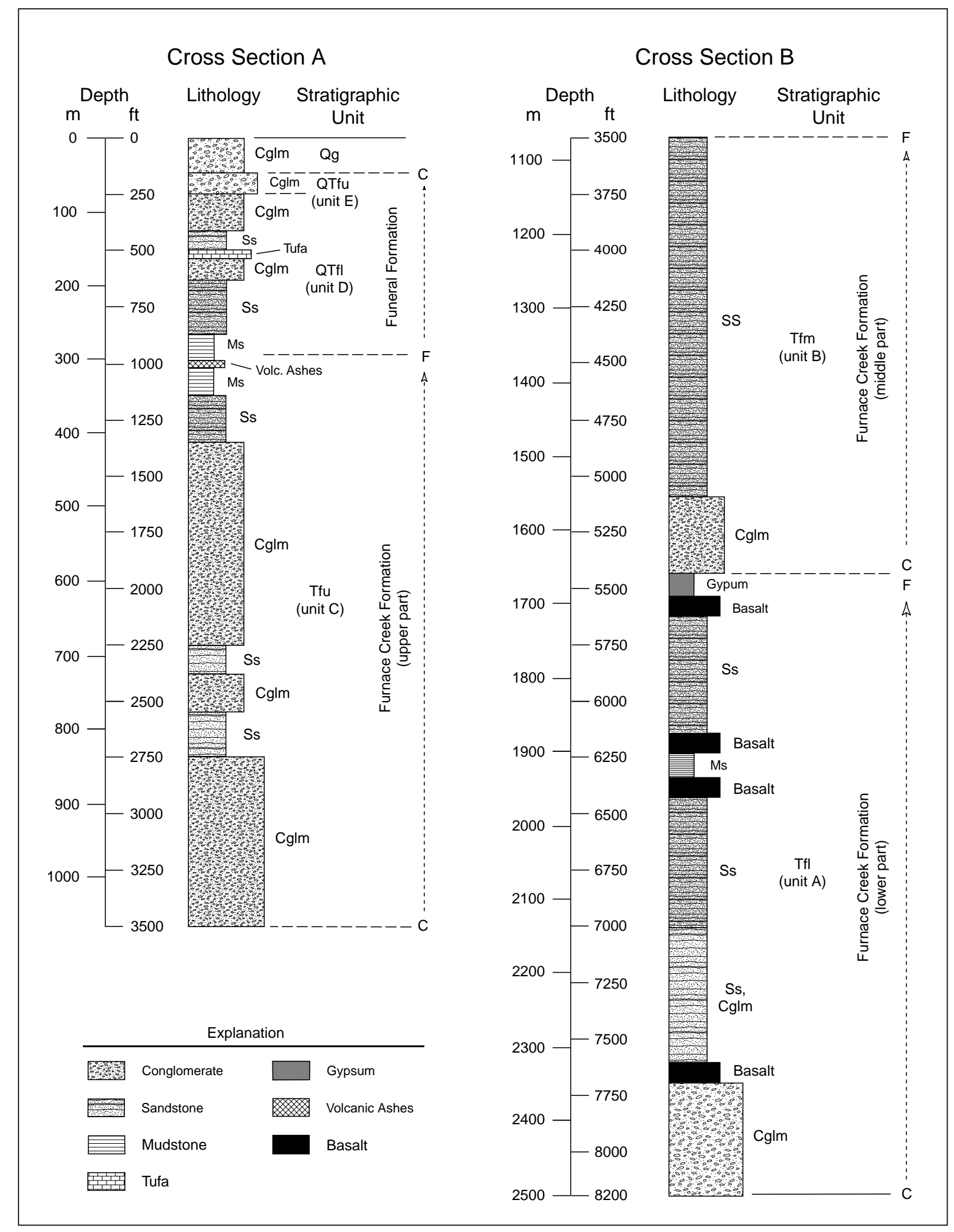

FIGURE 2. Generalized lithologic and stratigraphic column for Texas Springs syncline. Major lithologies shown are based on surface outcrop; note that most of the conglomerates in the Furnace Creek Fm. become finer-grained to the northeast, into the syncline. Thicknesses estimated from cross sections $A$ and $B$ of McAllister (1970). Dashed arrows indicate general trend in grain size; C, coarse and F, fine. 
During the Pliocene (5-1.6 Ma), deformation continued to shape the geometry of the basin and greatly influence deposition of the Furnace Creek Formation. Continued deformation occurred along the detachment faults in the northern Black Mountains, coupled with right lateral displacement on the Furnace Creek and Death Valley faults, and normal displacement on the Cross Valley fault (figure 1). These forces combined to produce dextral (right-lateral) shear across the Furnace Creek Basin and development of a pronounced syncline and associated anticline.

\section{Funeral Formation}

The Funeral Formation is the uppermost basin-fill unit of the Furnace Creek basin. It records the uplift and unroofing of Paleozoic (mainly limestones and dolomites) of the Funeral Range, which bounds the basin on the northeast (figure 1). These clast lithologies record westerly depositional directions, whereas clasts within the medial and lower parts of the underlying Furnace Creek Formation are dominantly volcanic and volcanoclastic, recording northerly and northeasterly depositional directions from the Black Mountains (see Wright and others, 1999). It appears that McAllister's (1970) decision to split the Furnace Creek and Funeral Formation was based on grain size (coarsening upward for the Funeral Formation) rather than lithology (figure 2). Thus, as mapped, the Funeral Formation is derived from both the Black Mountains (to the south) and the Funeral Range (to the northeast).

The lower part of the Funeral Formation, which is well exposed 1-1.5 km east of Zabriskie Point (figure 1), consists of a coarsening-upward section of siltstones, sandstones, and volcanoclastic conglomerates (unit D, figure 2; McAllister's unit QTfl). The clasts are mainly volcanic in the lower beds, but become progressively more limestone rich in the upper part, indicating that the Funeral Range is becoming a source for the gravels. The gravelly beds are locally cemented with calcite and travertine, especially so upward in the section.

The upper part of the Funeral Formation is also well exposed about $2 \mathrm{~km}$ east of Zabriskie Point (figure 1), where it forms a prominent gravel-cored (and capped) ridge. The gravel dips northeastward commonly at $25^{\circ}-40^{\circ}$ (unit E, figure 2; McAllister's unit QTf) into the Texas Springs syncline. The clasts are entirely derived from Paleozoic limestones, dolomites and quartzites of the Funeral Range and are well cemented with calcite and travertine. These cemented conglomerates are identical to the "type-section of the Funeral Formation" (which is exposed along Highway 190 to the east), although probably occupy a higher stratigraphic position (more basinward and younger) in the study area.

\section{Texas Springs Syncline}

The Texas Springs syncline is named for Texas Springs, which issue from the western limb of the syncline. These springs are a major surface-water source of the Furnace Creek area. A second major water source is the Travertine Springs area, which is located south of Texas Springs and north of Furnace Creek Wash (figure 3).

The NNW-SSE trending Texas Springs syncline is an asymmetric fold that deforms siltstone, sandstone, and conglomerate of the Furnace Creek Formation (units A-C, figure 2), and sandstone and conglomerate of the overlying Funeral Formation (units D and E, figure 2). In addi- 


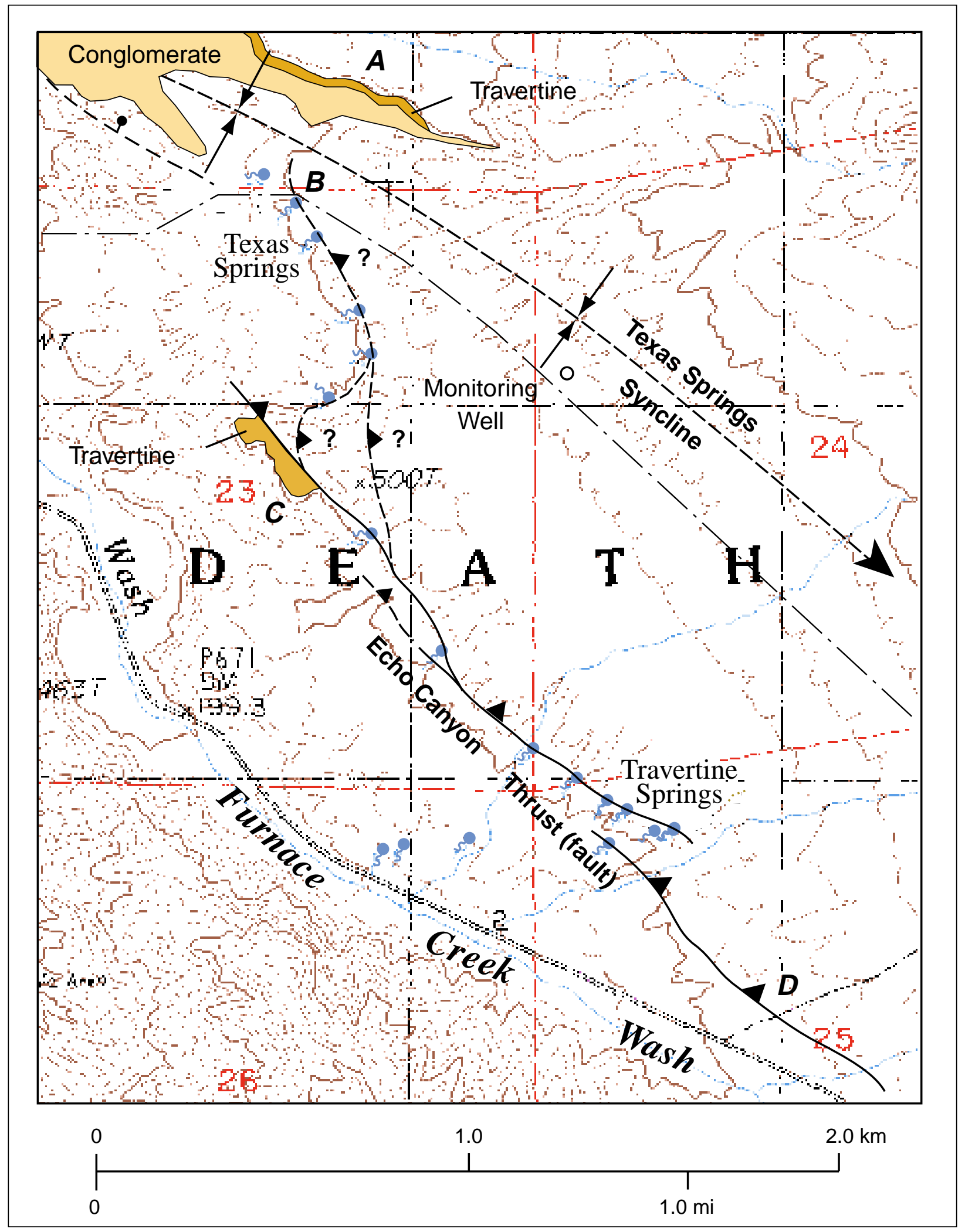

FIGURE 3. Aerial map of Texas Springs syncline showing location of geologic feature,s monitoring well, and major springs mentioned in text (base map from USGS Furnace Creek 7.5 minute quadrangle). 
tion, younger Pleistocene and Holocene surficial materials (mainly alluvial-fan deposits) derived from Echo Canyon and adjacent drainages east of the study area are deformed by Quaternary folding. Deposits of the older (Miocene) Artists Drive Formation must also be present within the basal portion of the syncline, although these deposits are only exposed south of U.S. Highway 190, on the north margin of the Black Range.

The syncline is flanked by a subparallel anticline, which is best developed about $2 \mathrm{~km}$ to the northeast of Texas Springs (figure 1). The southwestern limb of the syncline is steeply inclined and locally faulted. McAllister's mapping (1970) of the Furnace Creek Formation shows $30^{\circ}$ to $65^{\circ}$ dips along Furnace Creek Wash and some sandstone along Highway 190 (figure 1) is nearly vertical adjacent to a possible NW-trending fault concealed beneath alluvium. However, detailed mapping by Machette (unpubl. data, 1999) and McAllister (1970) shows no important north-trending faults that cut upward in section to cross the south limb of the syncline, so this limb is considered to be largely intact and structurally coherent. McAllister (1970) was able to trace a fine-grained upper member of the Furnace Creek Formation (unit Tfu) along this limb of the syncline, from the Cross Valley fault (figure 1) northwest to the area of Texas Springs Campground. In addition, Machette has found a diagnostic suite of volcanic ashes within this unit that suggests a Pliocene age for Tfu (unit C, figure 2). Further analysis of the ashes by tephrochronologic and $\mathrm{Ar}^{40} / \mathrm{Ar}^{39}$ dating methods is required to specify the age range and sources of the ashes, but one particular pumice-bearing unit has been quite useful as a local marker bed. In summary, there is no evidence for major NE-SW-trending faults that cross the Texas Springs syncline from its southeastern termination at the Cross fault (NE-SW strike) to Travertine Springs (figure 1).

The northern margin of the Texas Springs syncline seems to be partially controlled by a NWSE-trending unnamed fault that was not mapped by McAllister (1970). Evidence for such a structure, which must lie concealed beneath recent alluvium, comes mainly from the abrupt change in bedding attitudes on the north margin of the syncline and from a marked thinning of the lower part of the Funeral Formation (unit D, figure 2), just northwest of locality A (figure 3) (Machette, unpubl. mapping, 1999).

The beds exposed on the northwestern nose of the syncline are comprised of a coarseningupward section of siltstone, sandstone, and conglomerate (units D, figure 2) with local travertine beds and travertine-filled fissures (see locality A, figure 3). McAllister (1970) considered these to be within the basal part of the Funeral Formation (McAllister's unit QTfl), which records uplift of the Funeral Range due to accelerated movement along the Furnace Creek fault. This section also shows an upward fanning (decrease) of bedding attitudes. Dip in these strata decreases from about $40^{\circ}$ at stream level to about $15^{\circ}$ in the travertine-cemented (ridgeforming) conglomerates (northwest of B, figure 3), suggesting that the Texas Springs syncline was developing during deposition of the Furnace Formation. Deposits of the Funeral Formation are probably thicker to the southeast where the syncline is deeper.

Klinger (1988) and Klinger and Piety (1996, 1999a, b) mapped and named the Echo Canyon thrust fault (figure 1), which displaces sediment of the Furnace Creek Formation and younger Quaternary alluvial deposits on the north side of Highway 190 (locality D, figure 3). The Echo Canyon thrust is actually a 50-200 m wide zone of subparallel thrust faults that trend WNW and place basin-fill sediment over Quaternary alluvium (see Klinger and Piety, 1999b, figure 8). Ralph Klinger (oral commun., 1999) considers the Echo Canyon thrust to be a bedding-plane 
flexural slip fault that is the result of ongoing folding of the Texas Springs syncline. Their investigations of stream gradients and fault scarp morphology (Klinger and Piety, 1996) indicate that both the syncline and the thrust are active. Machette (unpubl. mapping, 1999) has extended the mapped trace of the Echo Canyon thrust farther northwest, where it controls the location and flow of tens of springs in the Travertine Springs area. In addition, the Echo Canyon thrust has been the conduit for older (Quaternary?) travertines that outcrop as a series

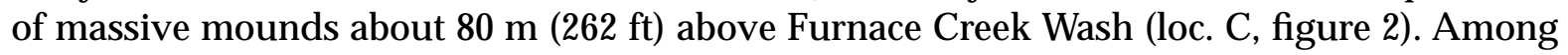
the dozen or so springs shown in the Travertine Springs area (Furnace Creek 7.5-minute map), the highest ones are along the most northerly trace of the thrust and are at a consistent elevation of 123-125 m (405-410 ft) (ASL, above sea level). To the north, this map shows six seeps at Texas Springs, five of which are at the same elevation. Thus, there appears to be a consistent maximum elevation for the discharge of waters both at Texas and Travertine Springs.

\section{Texas Springs monitoring w ell}

The first two seismic-reflection lines (DV-1, and DV-2) were placed close to an existing monitoring well that the U.S. Geological Survey drilled in November 1958. This well was drilled to

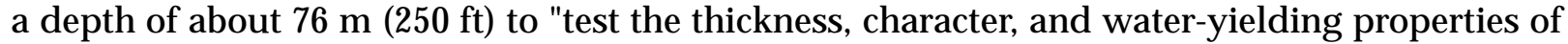
the deposits" in an area (Texas Springs syncline) where previous studies had postulated the presence of a ground-water body (Kunkel, 1959). The monitoring well is located about $1 \mathrm{~km}$ ESE of Texas Springs. The lithologic log of the well and test-pumping data were reported by Kunkel (1959), but the log lacks detail (i.e., clay, silt, sand and gravel). However, we have reinterpreted his major stratigraphic picks on the basis of exposures of laterally equivalent sediment about 1-1.5 km to the west and northwest, along the topographic escarpment at Texas Springs (locality B, figure 2).

Our interpretation of Kunkel's (1959) lithologic column shows about 38 m (125 ft) of uncemented to weakly cemented coarse-grained alluvium (unit E, figure 4) that we suspect is

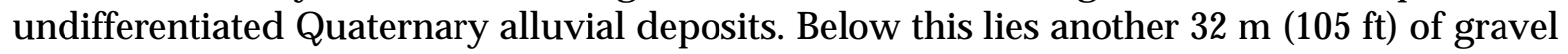
that we correlate with the upper part of the Funeral Formation (38-70 m, unit D, figure 4). These two units are similar in lithology and grain size, having both been derived from the uplifted Funeral Mountains block, about $4 \mathrm{~km}(2.6 \mathrm{mi}$.) to the east. Unit D was designated as "fanglomerate" by Kunkel (1959) and we suspect that this is the same unit as the Funeral Formation conglomerate (McAllister, 1970) exposed on the rim of the Texas Springs syncline, $1.5 \mathrm{~km}$ northwest of the monitoring well (locality B, figure 3). Kunkel noted that the fanglomerate contains abundant pieces of onyx, which is probably equivalent to the banded (fissure and lenticular) travertine that is so prominent in exposures nearby. The basal $6 \mathrm{~m}(20 \mathrm{ft})$ of the well (unit D7) was reportedly in lacustrine deposits, which we suspect is the lower part of the Funeral Formation (unit D, figure 2) or the upper part of the Furnace Creek Formation (unit C, figure 2) if an unconformity exists in the section. These two units have an unclear (gradational) boundary in outcrop; McAllister's (1970) mapped contact is based partly on provenance of clasts, the Furnace Creek being derived predominantly from the Black Mountains (to the south) and the Funeral being derived from the Funeral Mountains to the east. Kunkel (1959) did not report clast lithologies, so it is impossible to confirm the formational status from his well report. 


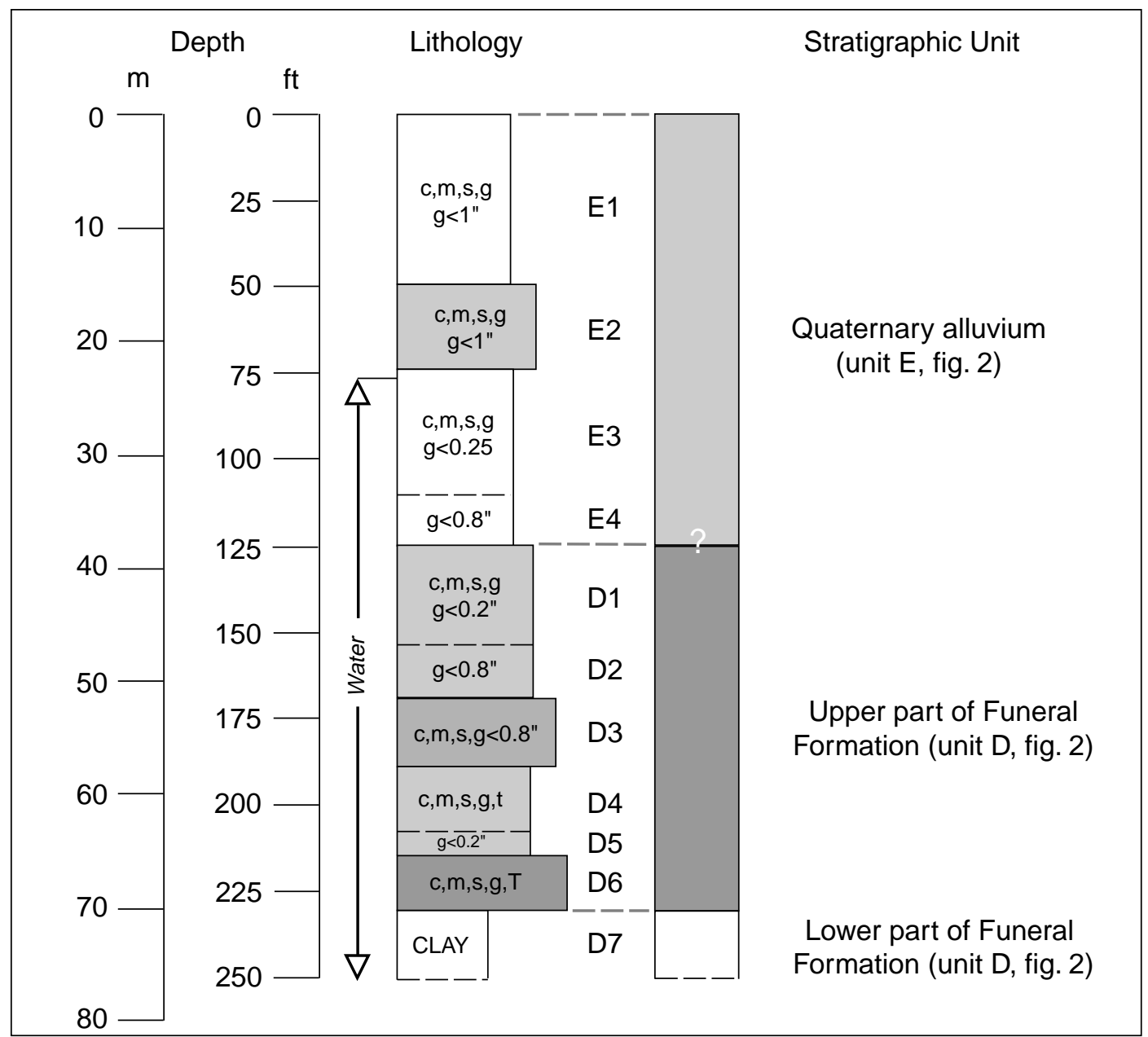

FIGURE 4. Lithologic and inferred stratigraphic column for the Texas Springs (1957) monitoring well. Modified from Kunkel $(1959, p$. 6). Abbreviations: $c$, clay; $m$, silt; $s$, sand; $g$, gravel; $t$, minor travertine (onyx), $T$, abundant travertine. Degree of shading is proportional to cementation of beds, as noted by Kunkel(1959). Triangle shows present water level in well.

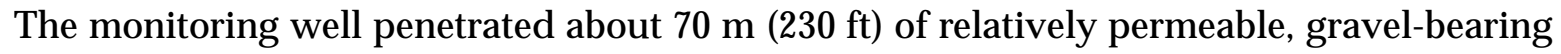
sediment. The basal $12 \mathrm{~m} \mathrm{(40} \mathrm{ft)} \mathrm{is} \mathrm{a} \mathrm{well} \mathrm{cemented} \mathrm{gravel} \mathrm{(D6)} \mathrm{and} \mathrm{lies} \mathrm{on} \mathrm{fine-grained} \mathrm{sedi-}$ ment (D7); as such, it probably forms an aquitard for laterally flowing water. The water level in the well was at $23.5 \mathrm{~m}$ (77 ft) in November 1958 (figure 3), whereas the current water level is at $23 \mathrm{~m}$ (76 ft), virtually unchanged over the past 40 years. Although Kunkel (1959) reported a well head elevation of $177 \mathrm{~m}(580 \mathrm{ft})$, our surveying indicates an elevation of $151.1 \mathrm{~m}(495.7 \mathrm{ft})$. The top of the well is about $0.7 \mathrm{~m}(2 \mathrm{ft})$ above ground level. Thus, the static water level in the Texas Springs monitoring well is at about $128 \pm 0.3 \mathrm{~m}(420 \pm 1 \mathrm{ft})$ elevation ASL (above sea level). This elevation is important because it relates to the elevation of both Texas and Travertine Springs, which generally issue at about 123-125 m ASL (405-410 ft ASL). 


\section{SEISMIC DATA ACQUISITION AND PROCESSING}

The three high-resolution seismic reflection profiles were acquired within the Texas Springs syncline as shown in figure 5. Approximately $4.2 \mathrm{~km}$ (2.6 mi.) of high-resolution seismic reflection data were acquired along pre-existing roads within the syncline. Line DV-1 (ENEtrending) is $0.6 \mathrm{~km}$ long, line DV-2 (SSE-trending) is $2.3 \mathrm{~km}$ long, and line DV-3

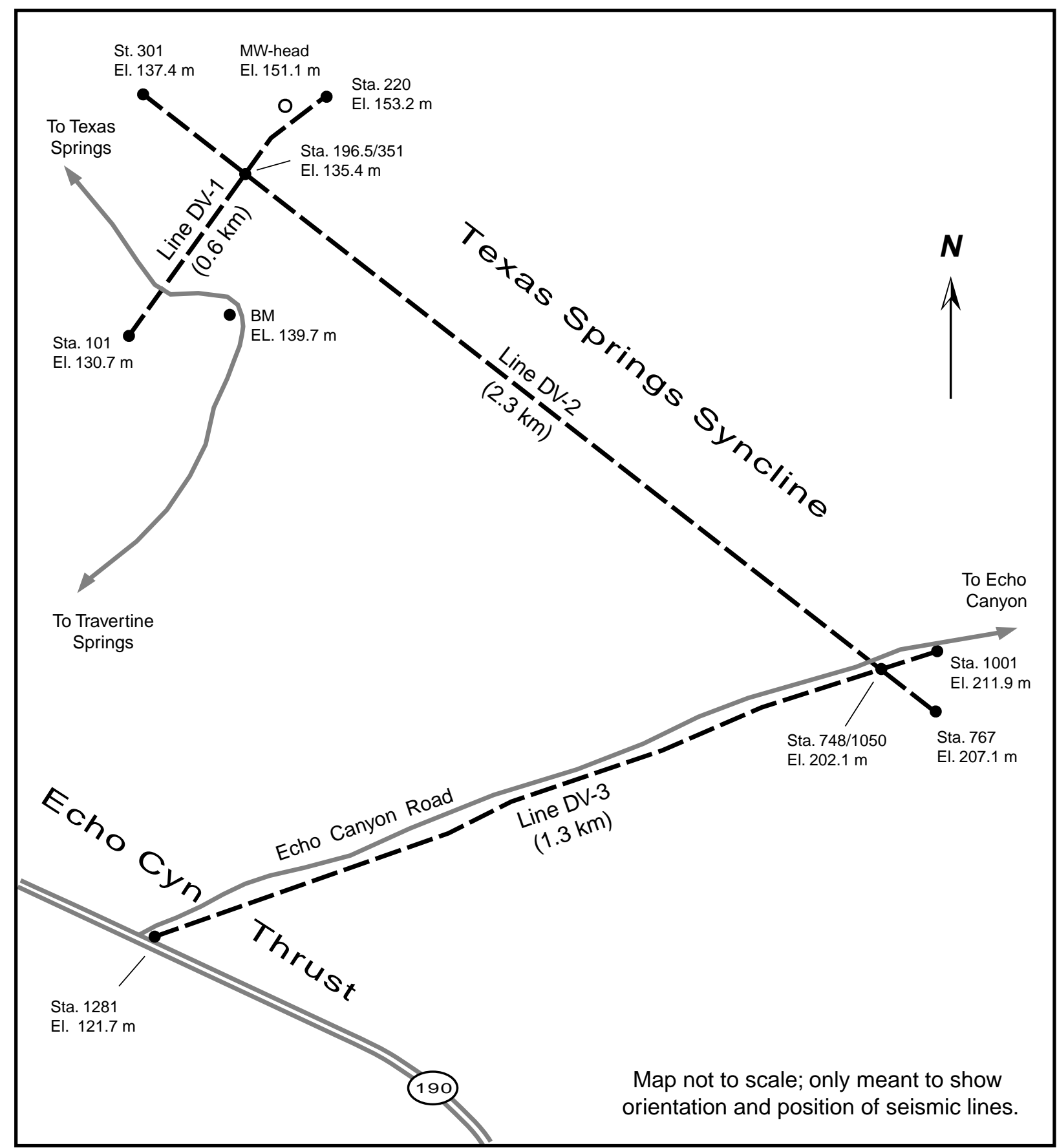

FIGURE 5. Planimetric map showing location and elevations of seismic-reflection lines and monitoring well near Texas Springs syncline. 
(WSW-trending) is $1.3 \mathrm{~km}$ long. The data presented herein were acquired with a 60-channel Geometrics StrataVisor seismograph and $28-\mathrm{Hz}$ resonant-frequency geophones (Table 1). The geophone and vibration (shotpoint) interval was $5 \mathrm{~m}$ using three geophones per station, thereby giving 30 -fold nominal common midpoint coverage.

The seismic-reflection data were acquired using the Mini-Sosie technique (Barbier, 1983). The key elements of the USGS Mini-Sosie acquisition system are its portable and nondestructive seismic sources, hand-operated earth tampers known as "wackers." Each time the foot of the wacker hits the ground, a sensor attached to the footpad transmits the exact impact time via radio transmitter mounted on a backpack to the recording truck (figure 6). The acquisition system records the impact time, along with 60 channels of data, and stores it in temporary memory. Impact signals and data are continuously recorded in the acquisition system until a specified length of recording time is attained. The seismic record that is written to disk is produced by cross-correlating the impact times and data channels. The Mini-Sosie method dramatically reduces the effects of short-duration cultural noise sources, such as automobile or pedestrian traffic, by summing up to eight individual records with as many as 2000 wacker impacts acquired over several minutes. Data for one 2000-impact shotpoint can be obtained in approximately 150 seconds (2.5 minutes). In this time span, transient seismic events essentially appear as random noise that is canceled out in the cross-correlation process.

Table 1. Generalized data acquisition parameters.

\begin{tabular}{|c|c|}
\hline Parameter & Description \\
\hline \multicolumn{2}{|c|}{ Source type ............................... Earth tampers (wackers) } \\
\hline \multicolumn{2}{|c|}{$\begin{array}{c}\text { Source array ….......................... Three wackers spaced roughly } 2.5 \mathrm{~m} \text { apart, aligned } \\
\text { parallel to seismic line }\end{array}$} \\
\hline \multicolumn{2}{|c|}{ Source point interval ................. $5 \mathrm{~m}$} \\
\hline \multicolumn{2}{|c|}{$\begin{array}{c}\text { Source duration ....................... Three } 12 \text {-second stacks of wacker impacts per } \\
\text { source point (approximately } 1000 \text { impacts) }\end{array}$} \\
\hline \multicolumn{2}{|c|}{ Geophone type .......................... 28-Hz resonant frequency, vertical component } \\
\hline \multicolumn{2}{|c|}{ Geophone array ......................... 3 geophones in 1-m diameter point cluster } \\
\hline \multicolumn{2}{|c|}{ Geophone group interval .........5 m } \\
\hline \multicolumn{2}{|c|}{$\begin{array}{r}\text { Shooting geometry …................ } 60 \text { channels, end-on (recording channels are ahead } \\
\text { of the wackers; } 5 \mathrm{~m} \text { near-channel offset (distance } \\
\text { between wackers and first recording channel; } 305 \mathrm{~m} \\
\text { far-channel offset }\end{array}$} \\
\hline \multicolumn{2}{|c|}{ Field filters ................................. $60 \mathrm{~Hz}$ notch } \\
\hline \multicolumn{2}{|c|}{ Recording system ..................... Geometrics 60-channel StrataVisor } \\
\hline \multicolumn{2}{|c|}{ Sampling rate ........................... 1 millisecond } \\
\hline Recording time ..... & ... 1 second \\
\hline
\end{tabular}

Three wacker energy sources were typically operated simultaneously at each shot point to reduce the time needed to obtain the desired number of impacts. Because signal randomness is critical in the cancellation of noise during cross-correlation, each wacker operator manually varies impact speed (normally between 3 and 8 impacts per second) to create a semi-random series of impacts. The acquisition parameters used in this investigation are shown in Table 1. 


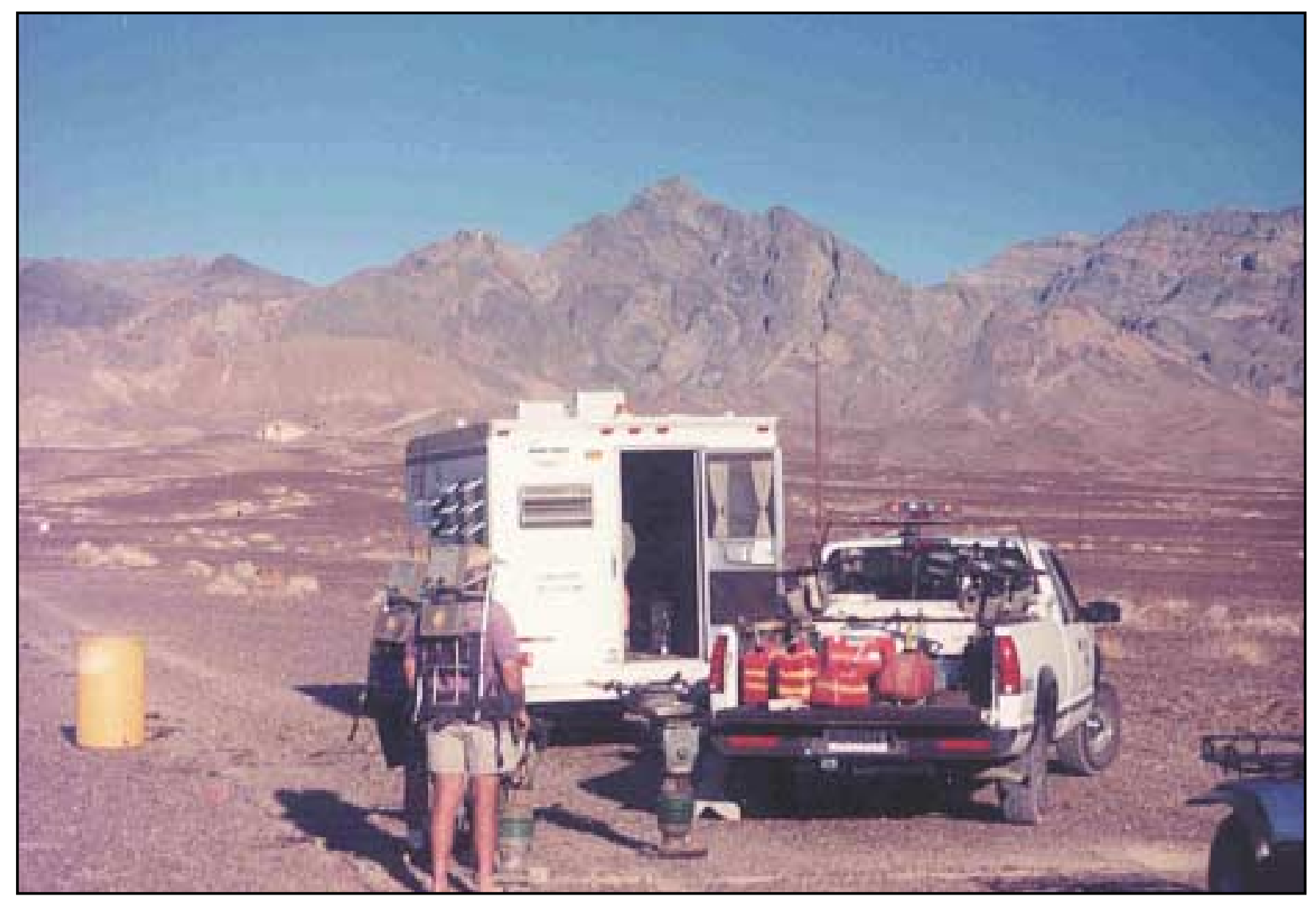

FIGURE 6. Photograph of seismic reflection equipment including hand-operated compactors (wackers), geophysical recording truck (doghouse), and transmitter (on backpack). Location is near access road that crosses line DV-1, view to the east (see figure 5).

The seismic processing we used was conventional for all three lines, and included trace editing, top muting, bandpass filter, automatic gain adjustment, deconvolution, air-blast attenuation, datum statics, residual statics, normal moveout, dip moveout (pre-stack partial migration), stack, and time-to-depth conversion (Table 2). A thorough discussion of these processing and signal analysis steps can be found in Yilmaz (1987). The majority of the signal frequency bandwidth in these data is between 50 and $200 \mathrm{~Hz}$, reasonably good to ensure data resolution.

Even though the Texas Springs syncline is generally a seismically quiet area, several factors degraded the data quality and forced the use of slightly different processing sequences on the seismic reflection profiles. Specifically, DV-1 (figure 7) required additional processing to eliminate strong coherent linear noise caused by what is believed to be surface waves (Table 2). This coherent noise was not as strong on either line DV-2 or DV-3 (figures 7 and 8). Line DV-2 had a very unusual $302 \mathrm{~Hz}$ resonation in many of the shot records, particularly on the earlier part of the line, that required additional notch filtering. The source of this interference is unknown but may be related to the power line overhead of the seismic profile.

Estimating seismic velocities is a critical step in determining correct reflector depths (typically stratigraphic or lithologic boundaries). Velocities are estimated by analyzing the variation in reflection arrival time with receiver offset in the unstacked seismic data (Yilmaz, 1987). Even in data with a high signal-to-noise ratio, estimates can be off by as much as 10 percent. The data 
Table 2. Generalized processing steps for seismic reflection profiles $D V-1, D V-2$ and $D V-3$.

\begin{tabular}{|c|c|}
\hline Processing Step & Comment \\
\hline Data Reformat .......... & Convert from SEG-2 to ProMAX® internal \\
\hline Geometry ................... & Install coordinate data into trace headers \\
\hline Trace Edit ................................. & Kill bad traces, fix polarity reversals \\
\hline 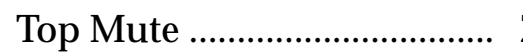 & Zero all data amplitude before and including first arrivals \\
\hline Bandpass Filter $(\mathrm{Hz})$............... & 40-80-250-500 Hz; $60 \mathrm{~Hz}$ notch; $302 \mathrm{~Hz}$ notch $^{1}$ \\
\hline AGC & Adjust amplitudes using 400 ms RMS gain window \\
\hline $\begin{array}{l}\text { Adaptive spiking } \\
\text { deconvolution ................ }\end{array}$ & L2-norm, 200 ms operator length \\
\hline Air Blast Attenuation ............. & Attenuate high-amplitude air wave at $340 \mathrm{~m} / \mathrm{s}$ \\
\hline 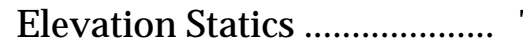 & Time-shifts traces based on station elevation \\
\hline Sort to CMP ............................... & Reorder data by common midpoint number \\
\hline NMO correction ...................... & Apply stacking velocities (best of 3 analysis passes) \\
\hline Residual statics ...................... & $\begin{array}{l}\text { Surface-consistent, based on maximum stack power; } \\
\text { apply results of two passes }\end{array}$ \\
\hline 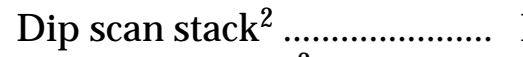 & Remove additional coherent linear noise events \\
\hline Spectral shaping ${ }^{2}$.................... & 40-80-200-400 Hz frequency-domain deconvolution \\
\hline Dip decomposition DMO .... & Dip move-out correction \\
\hline 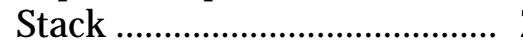 & Zero-offset mean stack \\
\hline Time-to-depth conversion .... & Digital conversion using best stacking velocity function \\
\hline
\end{tabular}

ProMAX® is a registered trademark of Landmark Graphics Corporation Note 1. 302-Hz notch applied to line DV-2 only

Note 2. Process applied to line DV-1 only 


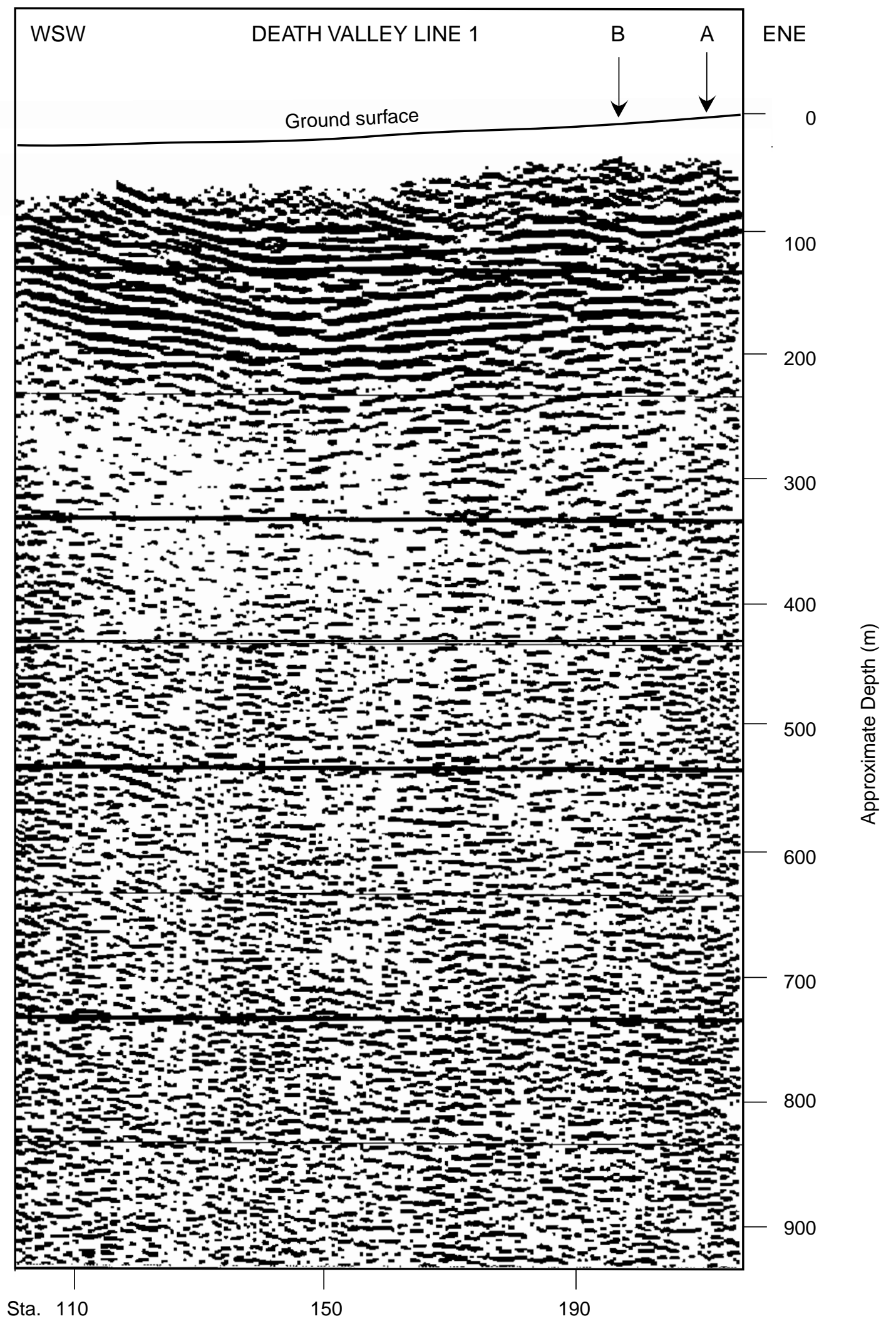

FIGURE 7. Uninterpreted processed seismic-reflection profile DV-1. Depths are relative to the surface at the eastern end of the line. A is location of monitoring well, B is point of intersection with profile DV-2. 


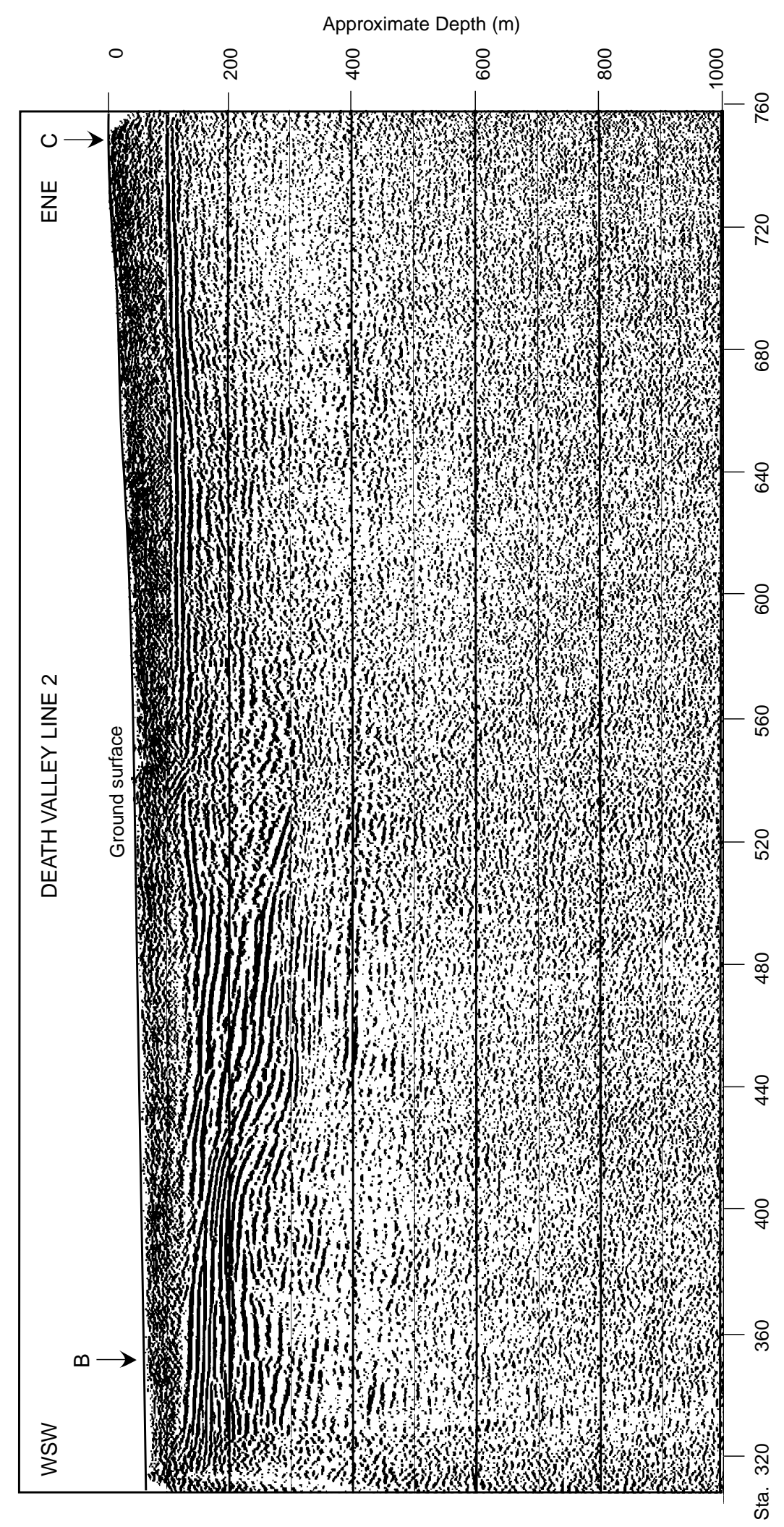

FIGURE 8. Uninterpreted processed seismic-reflection profile DV-2. Depths are relative to the surface at the eastern end of the line. $B$ is point of intersection with profile $D V-1, C$ is point of intersection with profile $D V-3$. 


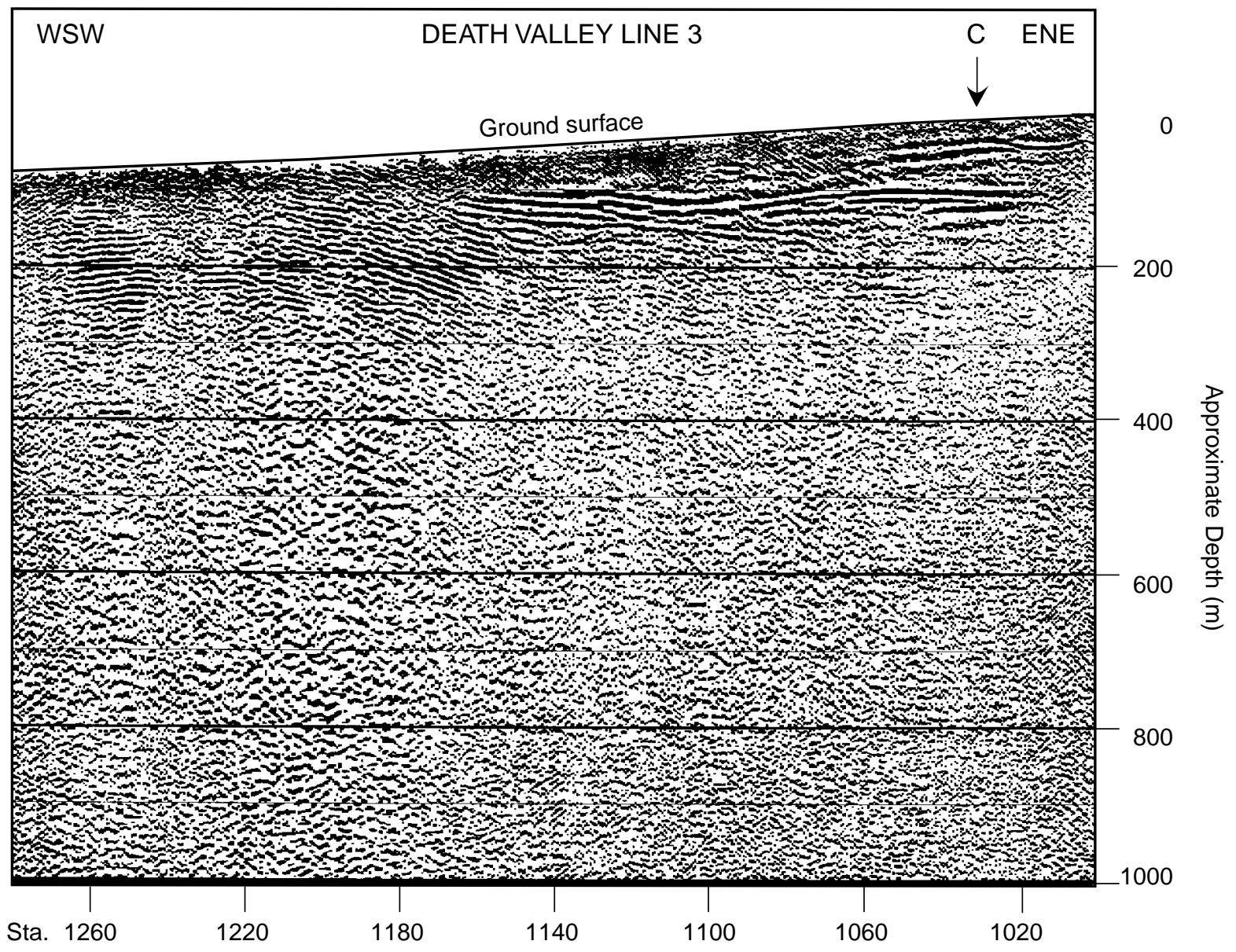

FIGURE 9. Uninterpreted processed seismic-reflection profile DV-3. Depths are relative to the surface at the eastern end of the line. $C$ is point of intersection with profile DV-2.

collected within the Texas Springs syncline are considered to be of moderate signal-to-noise, and we believe our velocity estimates are certainly within this 10 percent bound. Estimated interval velocities in these data range from $1400 \mathrm{~m} / \mathrm{s}$ at the surface to over $2800 \mathrm{~m} / \mathrm{s}$ at 200 meters depth. These data show roughly linear velocity increases with depth, which is a common occurrence in young sedimentary basin deposits owing to progressive burial and consolidation (dewatering and densification). The sections presented here have all been converted to depth using the stacking velocities that best enhanced the stacked sections during data processing.

\section{GEOLOGICAL INTERPRETATION}

Texas Springs syncline is the main target for developing a long-term production well for the Furnace Creek area. The doubly plunging syncline is, in a simplistic view, an elongate basin that is deepest in its central part (probably near Echo Canyon Road), several kilometers southeast of the monitoring well. Most of the basin is filled by fine-grained sediment (figure 2; units A-C, siltstone and sandstone of the Furnace Creek Formation; unit D, basal part of the Funeral Formation), but the upper part is filled by coarse-grained facies of the Funeral Formation (unit 
E, figure 2) and capped by younger Quaternary alluvium. These gravel-bearing sediments are probably the main aquifer for Texas and Travertine Springs. The gravel is folded within the syncline, albeit to a lesser extent than the underlying fine-grained sediment, which acts as a local aquitard. Much of the current water production for Furnace Creek Ranch and adjacent facilities is coming from surface springs on the west and southwest margins of the syncline (figure 3). We think it is no coincidence that there is a common elevation for the highest of the springs-about 123-125 m ASL (405-410 ft). The current water level in the monitoring well is at about $128 \mathrm{~m}$ ASL (420 ft); it is located about $1 \mathrm{~km}$ ESE of Texas Springs and about $0.6 \mathrm{~km} \mathrm{E} \mathrm{of}$ the most southerly of the springs in this area. Thus, it appears that there maybe as little as 3-5 $\mathrm{m}$ (10-15 ft) of head (water elevation) between the monitoring well and the springs. Water flowing west-northwest to Texas Springs would have a minimum (E-W) ground-water surface gradient of about $3-5 \mathrm{~m} / \mathrm{km}(10-15 \mathrm{ft} / \mathrm{mi}$.), and those waters flowing due west $(0.6 \mathrm{~km})$ would have a minimum (E-W) gradient of about $5-8 \mathrm{~m} / \mathrm{km}(15-25 \mathrm{ft} / \mathrm{mi}$.). One downside to a new production well is the possible drawdown of water levels near Texas Springs. Luckily, the current monitoring well is positioned such to detect water level changes above the springs.

Of the three seismic-reflection lines (figures 6-8), DV-1 and DV-2 are the most relevant to locating a new production well close to Texas Springs. However, if a decision is made to locate the well farther afield, then line DV-3 along Echo Canyon Road would be relevant. We discuss the results of each of the three seismic-reflection lines separately below.

\section{Line DV-1}

Line DV-1 extends from the western margin of the sediment-filled valley that is formed by the Texas Springs syncline, east-northeast ( $\left.54^{\circ}-60^{\circ} \mathrm{E}\right)$ past the monitoring well, a distance of about $592 \mathrm{~m}$ (ca. $0.6 \mathrm{~km} ; 0.4 \mathrm{mi}$.). The line was placed almost perpendicular to the projected trace of the syncline according to 1:24,000-scale geologic mapping of McAllister (1970). The west end (sta. 101, figure 5) is on an alluvial channel that cuts through gravel-capped hills (upper Funeral Fm.?) that lie on fine-grained sediment of the lower part of the Funeral Formation (unit QTfl). In the field, these two units appear to be separated by either an angular sedimentary unconformity and/or a low-angle fault (figure 3) that eliminates some of the upper part of the Funeral Formation (this relation has not yet been solved by geologic mapping). Unfortunately, the first shot point for DV-1 (sta. 101) was east of the unconformity and we would have needed at least an additional 10 stations (50 m spread) on the west end of the line to acquire reflection data that could image this east-dipping feature in the near subsurface. Nevertheless, either explanation yields a potential ground-water barrier along which (or across which) springs waters are now issuing. Farther to the east, line DV-1 crosses older Quaternary alluvium owing to progressive growth of the syncline and the resulting downstream convergence (E to W) of Quaternary surfaces. At the monitoring well (figure 5), the surface is underlain by alluvium that has a strongly varnished desert pavement, clay-enriched Bt horizon, and significant calcium carbonate cementation as seen in occasional gully walls north and south of the line. Soils of this type may be as much as 100,000 years old in the Death Valley area (see Machette and others, 1999).

For our interpretation of line DV-1, we used the log from the monitoring well (figure 4) to provide control for the top of the ground-water table and correlated the significant change in grain size (from gravels to clays, figure 4) at the base of the well to a stratigraphic boundary with the Funeral Formation (unit D, figure 2). This contact probably coincides with McAllister's (1970) 


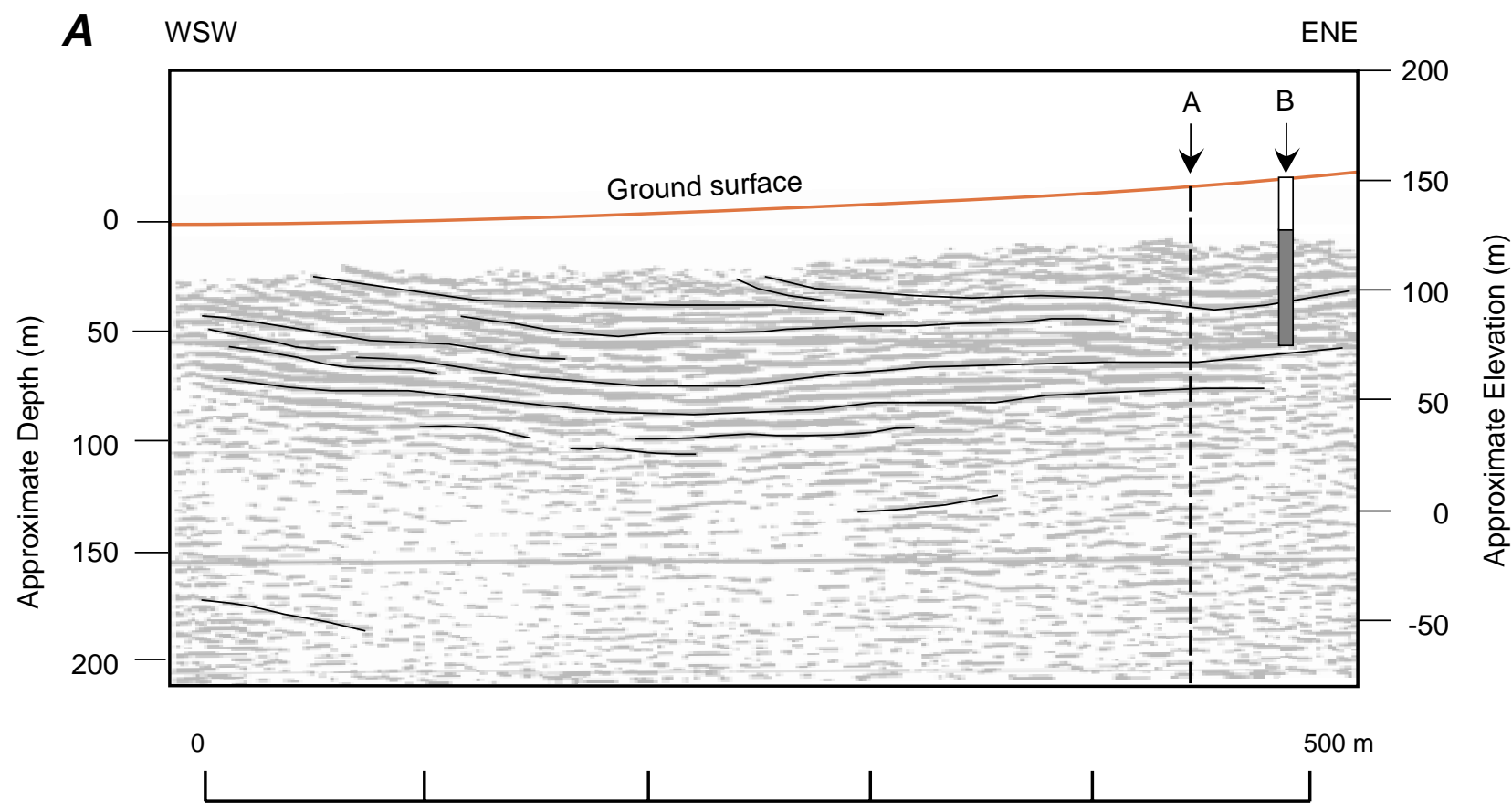

B

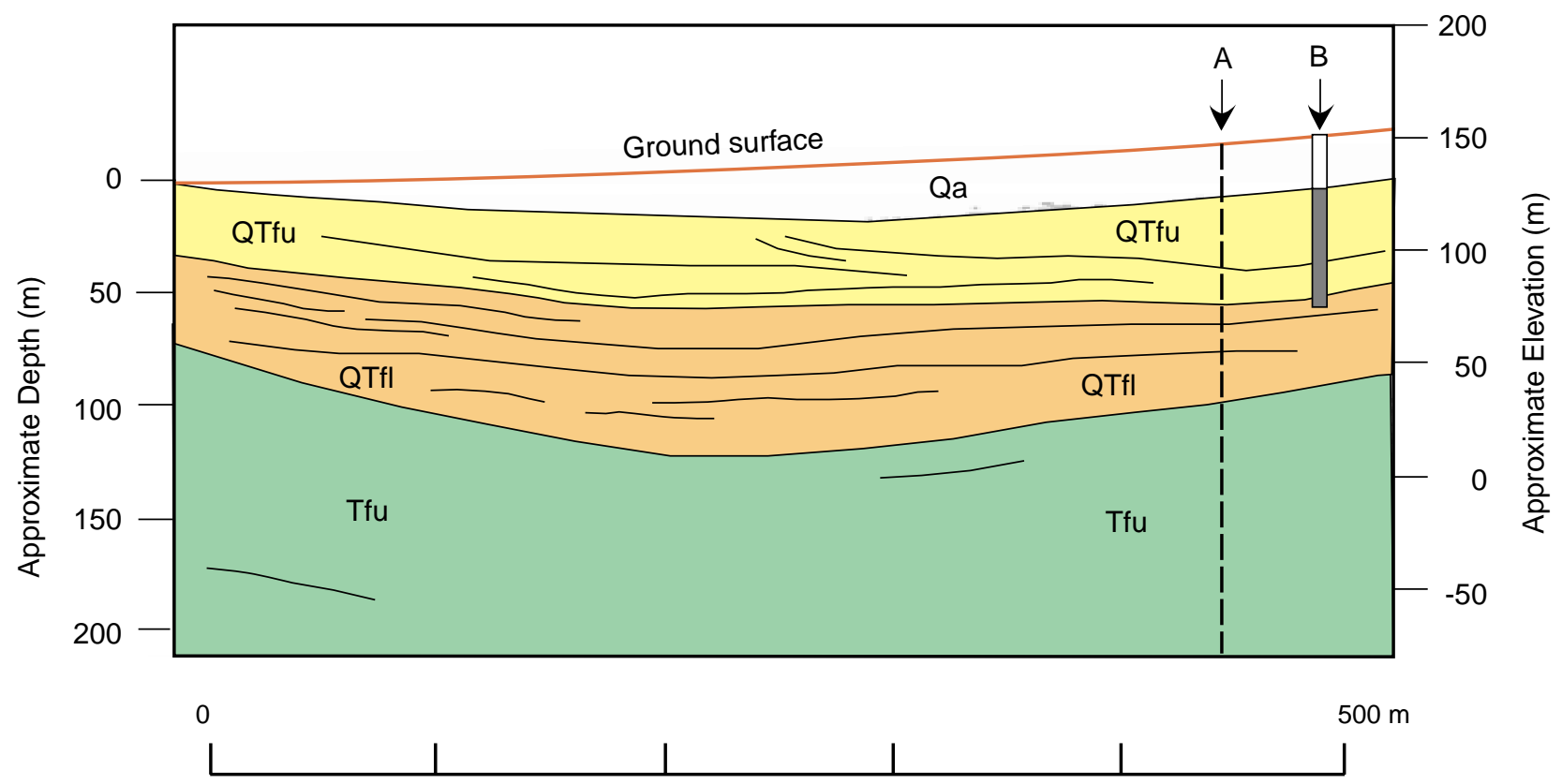

FIGURE 10. A, Processed seismic line DV-1 showing prominent reflectors. B, Interpreted geologic section along DV-1. Geologic units: Qa, undifferentiated Quaternary alluvium; QTfu, upper (gravelly) part of Funeral Fm.; QTfl upward-coarsening lower part of the Funeral Fm.; Tfu, fine-grained upper part of the Furnace Creek Fm. A is where line DV-2 intersects DV-1; B is location of monitoring well. Gray portion of well (B) shows water-bearing section of well 
boundary between unit QTfu (coarse-grained upper part of the Funeral Fm.) and unit QTfl (finer-grained basal part of the Funeral Fm.). Our second line of evidence for the interpreted stratigraphy and structure is the general lack of reflectors in unit QTfu (gravels) and the consistent pattern of parallel to gently folded reflectors within unit QTfl, which probably results from the interbedding of sandstone, mudstone, and conglomerate. The reflectors (figure 10a) within these units may represent grain-size contrasts and/or velocity contrasts. The lower portion of the record section (unit Tfu) is largely devoid of coherent reflectors: this may be the result of poor seismic penetration in the upper part of the Furnace Creek Formation which is markedly finer grained in the syncline than shown in figure 2 (unit C). Although shown as a sharp contact, the boundary between units QTfl and Tfu is most likely a gradational boundary that has low-angle unconformities along the southwestern and northeastern margins of the syncline associated with deposition during fold growth.

On the basis of these interpretations, we believe that units QTfu and QTfl are the main aquifers within the Texas Springs syncline in the vicinity of the monitoring well (figure 10b). If this is the case, then a well would only need to penetrate $110-130 \mathrm{~m}(360-425 \mathrm{ft})$ of section along line DV-1 to go through the reflectors that represent the coarse-grained aquifer unit. This does not seem to be a very thick aquifer for a major water-production well as compared to the potentially thicker section revealed to the south-southeast along line DV-2.

We note that deeper reflectors were imaged in DV-2 at the point were it crosses DV-1. Two factors are believed to have contributed to this. First, the shooting geometry changed as acquisition approached the northeastern end of the line DV-1 (sources continued to advance northeast while receiver array did not), which ultimately caused loss of reflected signal from possible deeper reflections because the number of far-receiver offset was reduced. Second, the strong linear coherent noise discussed in the processing section possibly degraded deeper reflections in DV-1 even after the additional processing steps (Table 2).

\section{Line DV-2}

Line DV-2 extends from the northern part of the sediment-filled valley that is formed by the Texas Springs syncline, south-southeast (S. $50^{\circ}-55^{\circ}$ E.) past the monitoring well to just past Echo Canyon Road for distance of about $2.3 \mathrm{~km}$ (ca. $1.4 \mathrm{mi}$.). The line was positioned beneath a utility power line on a pre-existing road that was built several decades ago. The line roughly parallels the projected trace of the syncline according to 1:24,000-scale geologic mapping of McAllister (1970). The northwest end (sta. 301, figure 5) is in relatively thin alluvium (unit Qa, figure 11) that lies on the upper and lower parts of the Funeral Formation (units QTfu and QTfl, respectively). As mapped, the syncline plunges gently to the southeast, so gravel-bearing units should thicken in this direction as indicated in the interpreted line (figure 11b).

To interpret line DV-2, we used the interpreted log from the monitoring well (figure 4) and carried the stratigraphic calls from DV-1 to DV-2. Our second line of evidence for the interpreted stratigraphy and structure is the consistent pattern of flat to gently folded reflectors within the upper part of the record section (figure 10a). As for DV-1, we believe that these reflectors represent the interbedded fine-grained section within the upper part of the Furnace Creek

Formation (unit C, figure 2). 

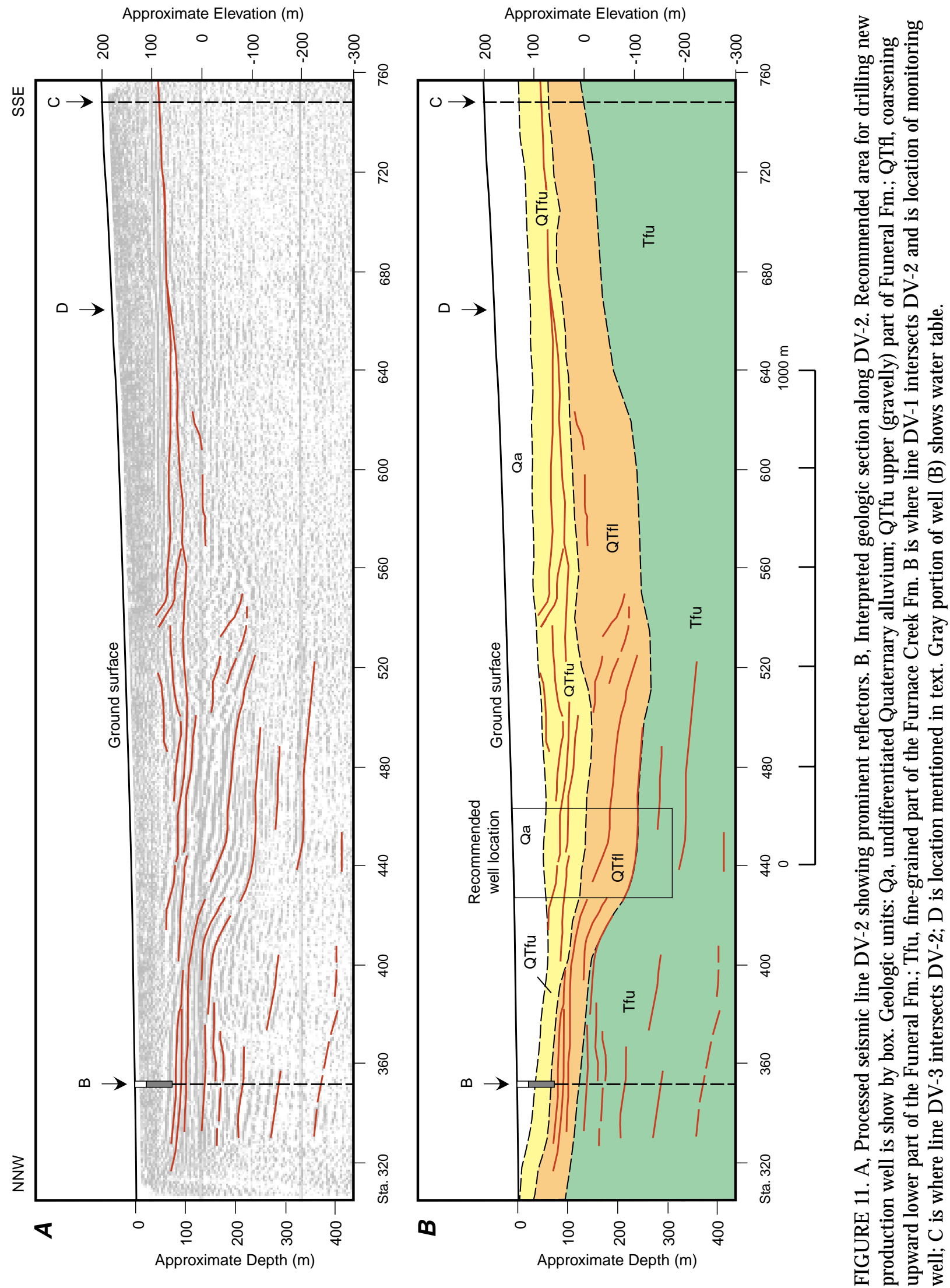
We expected line DV-2 to show very gently south-dipping but basically parallel, reflectors because of its orientation parallel to the synclinal axis. However, there is significant warping of reflectors below $100 \mathrm{~m}$ depth, especially between stations 400 and 460 . This geometry could be caused by geologic structure (either faulting or folding) or by depositional onlap (unconformities) related to the contemporaneous growth and filling of the syncline, or by some combination of the two. We discount a structural origin for the steeper reflectors based on a general lack of cross-syncline faults as noted from McAllister's (1970) mapping and the general continuity of the rim-forming travertine and conglomerate of the Funeral Formation, as shown in figure 1. It is possible, but considered unlikely, that there is blind faulting below the folded strata.

We interpret the upper part of the section (generally above 110-130 m depth) as the same sediment encountered in the monitoring well: undifferentiated Quaternary alluvium (Qa, figure 2 and $11 \mathrm{~b}$ ) and the coarse upper part of the Funeral Formation (QTfu, figure 2). The non-reflective section thickens to the southeast, in accord with the widening and deepening of the gentle south-plunge of the Texas Springs syncline (in this area). Unless alternately cemented and uncemented, the gravels generally will not have reflectors. Some of the apparent dipping reflectors may reflect low-angle cut and fill channel margins in unit QTfu. Below unit QTfu (figure 11b), we interpret a second southeastward-thickening section of interbedded sandstone, siltstone, and conglomerate (?) that belongs to the lower (upward-coarsening) part of the Funeral Formation (unit QTfl, figure 2). The coarser sediment within unit QTfl may provide local aquifers, in addition to the upper 110-130 $\mathrm{m}$ of the section.

Unit QTfl has strong reflectors that reveal progressive northwestward onlap between stations 400 and 540 (see figure 11b), about $245 \mathrm{~m}$ and $945 \mathrm{~m}(800-3100 \mathrm{ft})$ south-southeast of the monitoring well (respectively). This overthickened section between stations 400 and 540 and farther southwest is our designated bottom target for the NPS's planned production water well (see discussion).

Below unit QTfl, we see two distinct packages in the Furnace Creek Formation (Tfu): a northern one that contains sparse but prominent reflectors (north of station 520), and a southern one that contains no prominent reflectors (south of station 520). There are two possible interpretations for this relationship. First, this part of the section contains two lateral facies of the Furnace Creek Formation: a north (or northwest) facies that contains interbedded siltstone and sandstone and conglomerate, and a south (or southeast) facies that contains interbedded claystone, siltstone and sandstone. Wright and others (1999) noted that the thickest and finest grained sediment of the Furnace Creek Basin is to the southeast of Echo Canyon Road, tucked between the narrowing margins of the Funeral Range and the Black Mountains. This interpretation is supported by the mapping of McAllister (1970). Our conjecture that the north (or northwest) facies contains conglomerate is based on the mapped distribution of gravelly facies in the Furnace Creek Formation (see McAllister, 1970). The conglomerates are thickest and coarsest near Furnace Creek Inn (see figure 2, cross section A), but thin and become finer to the east. Thus, we believe that the lateral discontinuity of reflectors in unit Tfu (figure 11b) could represent an east and southeast fining within the Furnace Creek Formation. Alternately, a simpler interpretation involves a better depth of seismic signal penetration for the northern part of DV-2 than the southern part. 


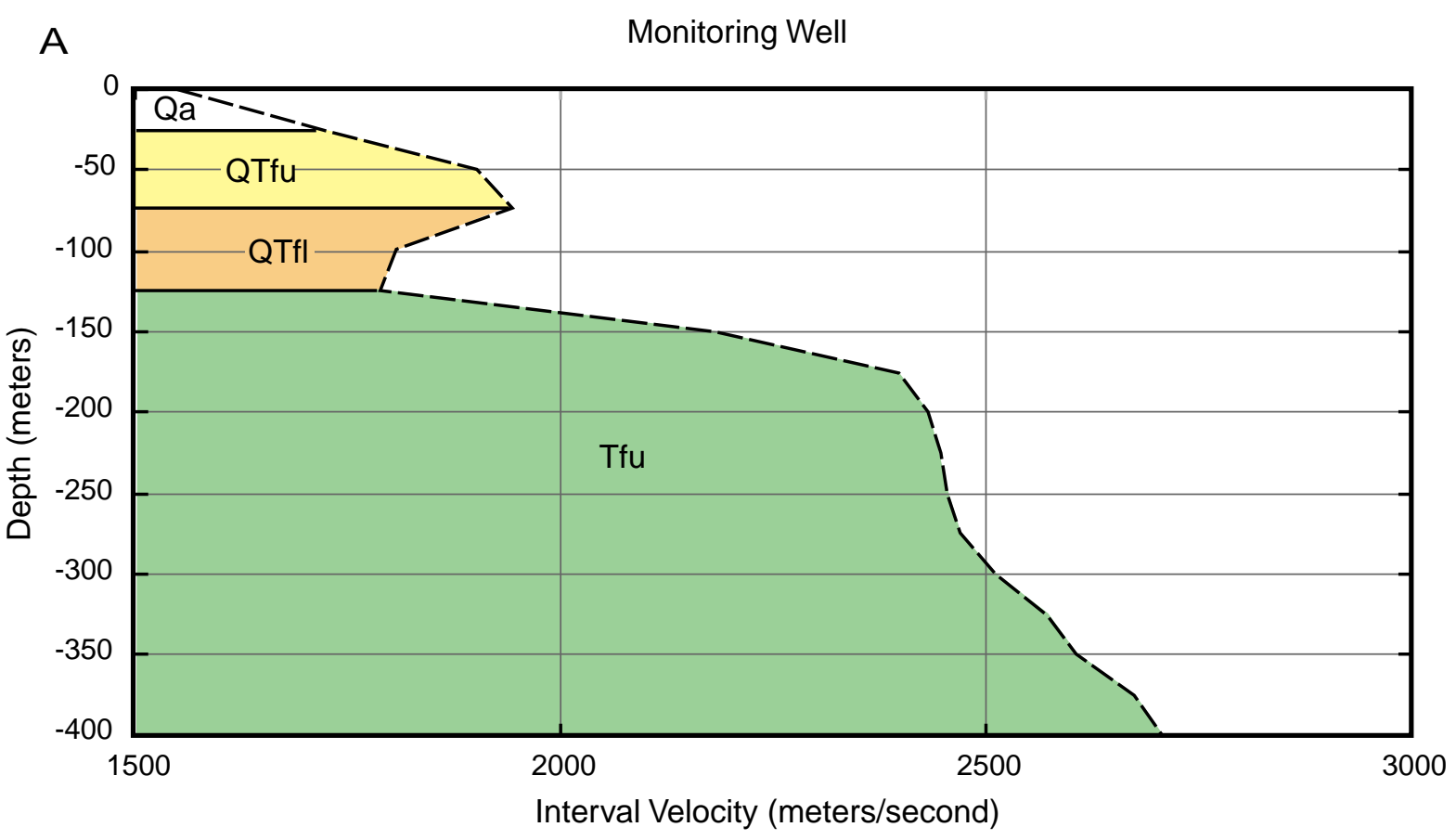

B

Station 665

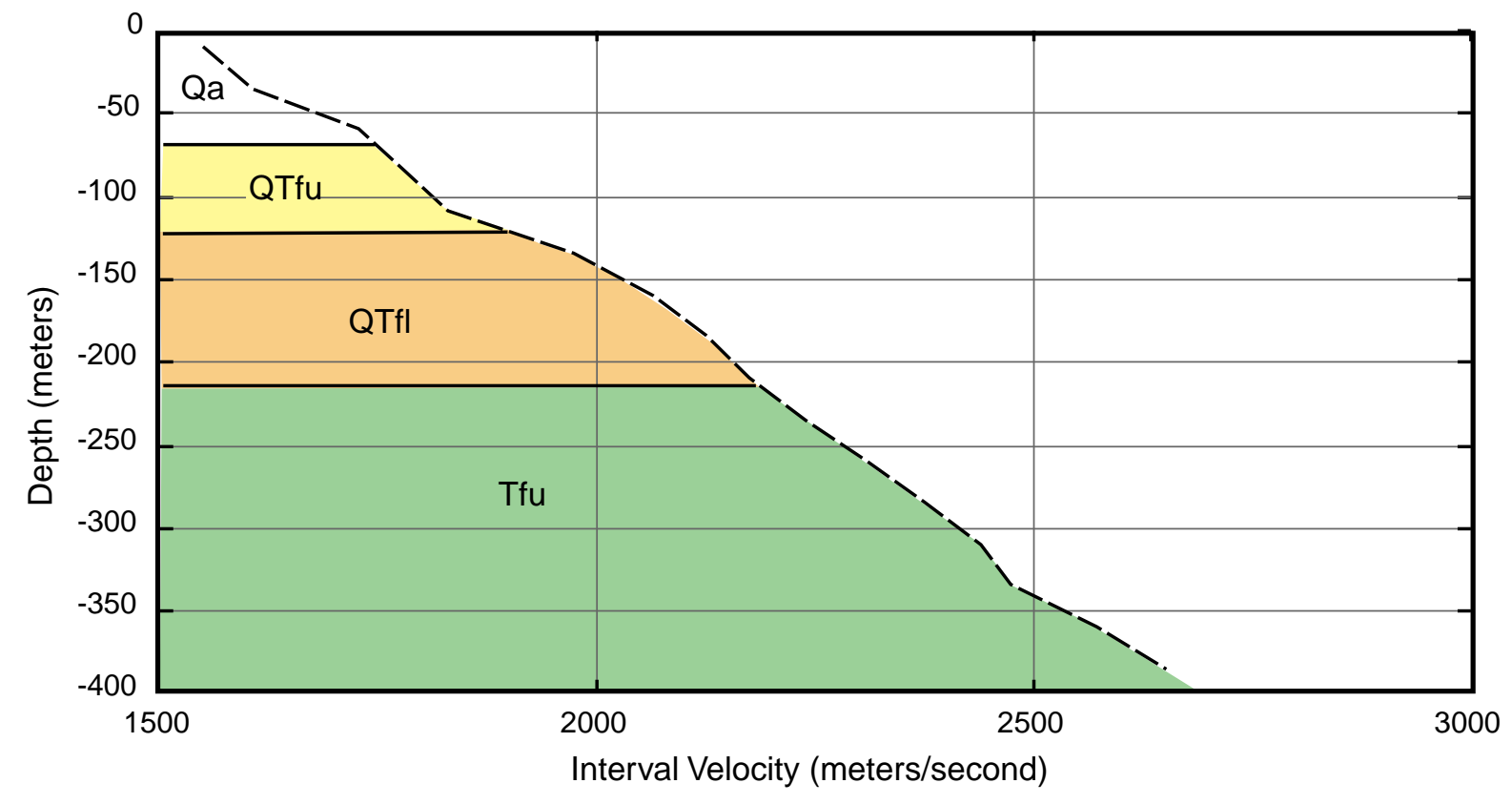

FIGURE 12. Interval velocity/depth curves from two locations along seismic line DV-2. Interval velocities were calculated from stacking velocities derived during data processing, averaged over 50 stations. $A$, Curve centered beneath monitor water well shows reasonable agreement with interpreted stratigraphic contacts. B, Interval velocities vary smoothly with depth beneath station 665. Geologic units shown in figure 2 and $11 b$ 
Because of the importance of line DV-2, we compared velocities to stratigraphic contacts at two locations along the line to better assess the validity of the interpreted horizon depths. Stacking velocities from 50 stations, centered about both the projected point of the monitoring-well (B, figure 11) and station 665 (C, figure 11), were averaged and converted to interval velocities. In figure $12 \mathrm{a}$, the resulting interval velocity curve at the monitoring well projection matches reasonably well with stratigraphic unit contacts picked from reflections on the stacked seismic section (figure 11b). The interval velocity curve from station 665 (figure 12b), on the southeastern side of the seismic profile, covers the same approximate range of velocities, but increases much more smoothly with depth. While the interval velocities are derived from the same stacking velocity field used to create the seismic stack on which the stratigraphic horizons were picked, it employs somewhat circular logic; however, it does add to the confidence in the data quality because two approaches suggest similar stratigraphic contact depths.

\section{Line DV-3}

Line DV-3 was acquired along Echo Canyon Road, which provided easy access for our geophysical equipment. The eastern (starting) end of the line (sta. 1001, figure 5) is about $250 \mathrm{~m}$ east of line DV-2, whereas the western end of the line (sta. 1281) is on the northeast margin of U.S. Highway 190. In all, the line extends about $1.3 \mathrm{~km}$ in a S. $60^{\circ} \mathrm{W}$. direction. DV-3 is perpendicular to the Texas Springs syncline, but only crosses its western limb according to 1:24,000scale geologic mapping of McAllister (1970). The entire line is on Quaternary alluvium, which fills the Texas Springs syncline. Near the western end of the line, the Echo Canyon thrust (fault) is exposed on the north side of the road (see figure 8, Klinger and Piety, 1999b). In this outcrop, fine-grained sediment of the Furnace Creek Formation is thrustover Quaternary alluvium.

The size of fault scarps varies along the thrust in accordance with the age of faulted surfaces, thus demonstrating a history of repeated movement. In addition, Klinger and Piety (1996) have shown that the syncline and fault have continued to be active in the late Pleistocene and probably the Holocene. Klinger and Piety $(1999 a, b)$ suggested that the fault is the result of bedding-plane flexural slip associated with continued folding of the Texas Springs syncline. If this is the case, then the thrust fault is probably not seismogenic (that is, capable of generating large earthquakes on its own), but rather slips in conjunction with movement on either the Furnace Creek or Death Valley faults to the east and west, respectively. The thrust dips gently to the east (flat to about $20^{\circ}-25^{\circ}$ ) in outcrop, and it probably does not cause any substantial velocity contrasts if it stays within bedding planes of the Furnace Creek Formation. Nevertheless, we drew the probable location of the fault on line DV-3 based on its measured dip in surface exposure.

Reflectors beneath the probable location of the thrust on the southwestern end of the profile are largely horizontal to subhorizontal (figure 13). This is in contrast to dips of $30^{\circ}-65^{\circ}$ measured in outcrops along strike to the northwest and southeast, and to the thick section of northeast dipping beds south of Furnace Creek Wash. Reflectors are dipping at $20^{\circ}-25^{\circ}$ ENE between stations 1150 and 1210 in the inferred hanging wall of the thrust, consistent with geologic dips observed in outcrop. However, data quality is significantly lower on the WSW end of the profile, possibly caused in part by the thrust faulting. It may be that the subhorizontal reflectors are coherent noise artifacts, such as remaining surface-wave energy. 


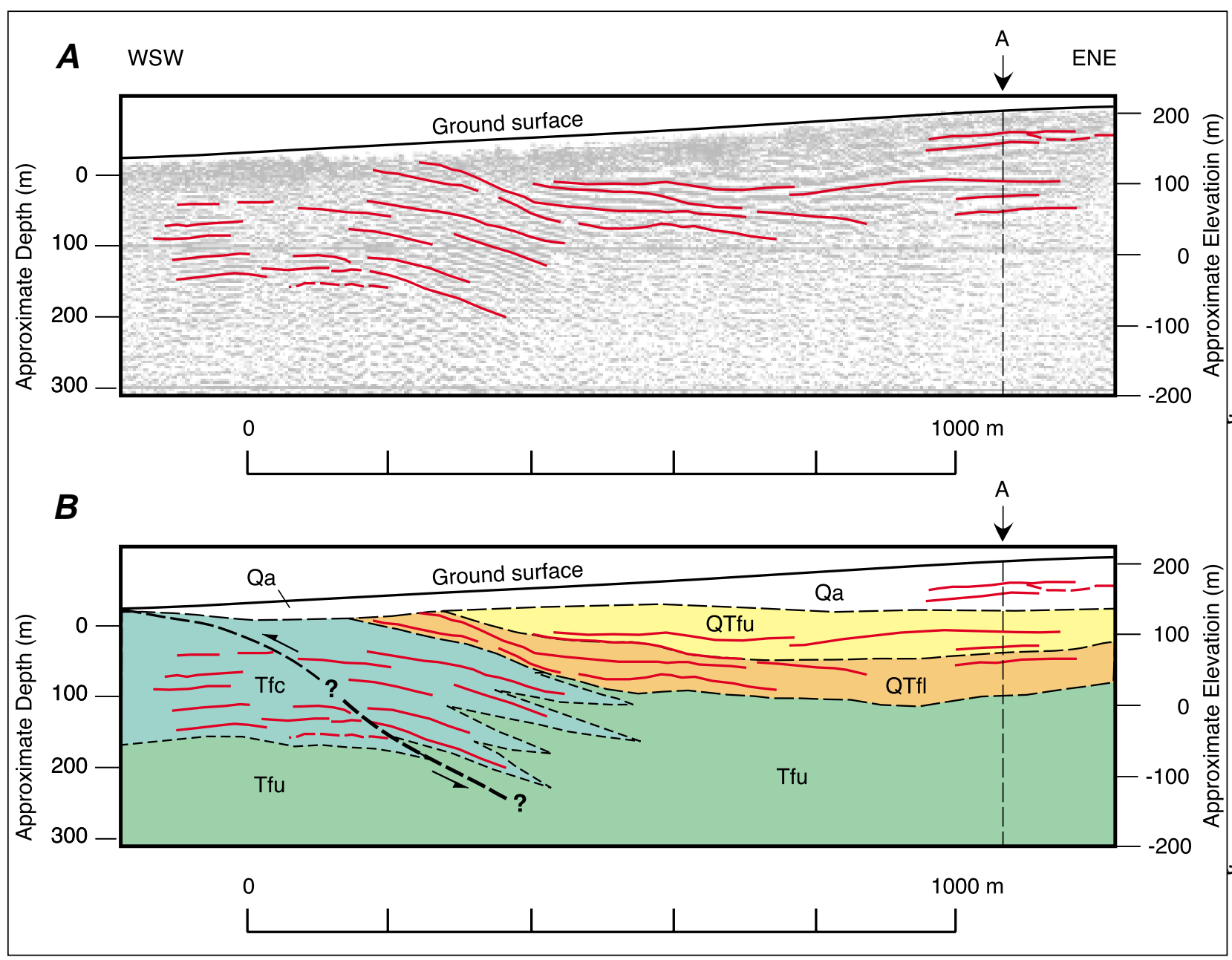

FIGURE 13. A, Processed seismic line DV-3 showing prominent reflectors. B, Interpreted geologic section along DV-3. Geologic units: Qa, undifferentiated Quaternary alluvium; QTfu, upper(gravelly) part of Funeral Fm.; QTfl, lower coarsening upward part of the Funeral Fm.; Tfu, fine-grained Furnace Creek Fm.; Tfc, coarse-grained Furnace Creek Fm. A is where line DV-2 intersects DV-3

If the National Park Services chooses to locate the new production well near or along the Echo Canyon Road, the subsurface geology we interpreted from line DV-3 suggests that the best location is in the medial portion of the line, where units Qa, QTfu, and QTfl may be nearly $200 \mathrm{~m}$ thick (figure 13b). Conversely, a location slightly further to the west (down slope and closer to Highway 190) may encounter a thinner sequence of these same deposits, but also has the possibility of intersecting the distal ends of coarse (?) grained facies of the Funeral Formation (unit Tfc, figure 13b) if a deep well is drilled.

\section{DISCUSSION}

About $4.2 \mathrm{~km}$ (2.6 mi.) of high-resolution seismic-reflection data was collected along three lines across and along the Texas Springs syncline, the primary drilling target for a new production for Death Valley National Park. From a purely geologic and hydrologic perspective, the most 
attractive drilling sites would be along the axis (center) of the syncline. Since it is doubly plunging, the central portion of the syncline should yield the thickest fill. Conversely the central, deepest portion of the syncline may contain less-porous finer grained sediment than the marginal areas.

The reflection data presented herein provide a method of detecting potential subsurface structure that is hidden at the surface and unpredictable from surface outcrops of the basin-filling sediment. Lines DV-1 and DV-3 produced subsurface images that are largely consistent with the expected geometry of the syncline. However, line DV-2 shows a series of southeast-dipping reflectors that are likely the result of warping and depositional onlap within the upper part of the Furnace Creek Formation (unit $C$, figure 2). This geometry produces a marked thickening of the basin-fill sediment between stations 400 and 540 and farther to the southeast (figure $11 b)$, an area that we identify as a prime site for a new well. If our contention that the reflectors in the lines are the products of velocity contrasts, then this area may contain significant thicknesses of interbedded mudstone, sandstone, conglomerate(?) that could act as aquitards or aquifers within the syncline. It is likely that the Quaternary alluvium and coarse-grained upper portion of the Funeral Formation are the primary aquifers. In addition, line DV-2 is close to the center of the syncline as determined from the mapped trace of the structure and from line DV1 . Thus, the site shown on figure $11 \mathrm{~b}$ provides a potentially thicker section of gravels as viewed along the axis and across the axis of the Texas Springs syncline.

Other considerations that favor the above mentioned well site are its proximity to the existing monitoring well, which provides a valuable resource for continued monitoring of the ground water level within the northwestern portion of the syncline. A second consideration is the site's proximity to the Texas Springs tunnel, which is the upper (eastern) end of the NPS's water collection and distribution system (i.e., hydrologic infrastructure). Finally, the prime site is near two existing roads: one beneath the powerline, and a second that extends from the TexasTravertine Springs road (see figure 4) to the powerline road. The latter road (albeit poor) would provide access for drilling equipment and for regular maintenance.

Possible drawdown of the water table is one disadvantage to a well site is the northeastern part of the Texas Springs. It seems no coincidence that the water level in the monitoring well is only 3-5 m (10-15 ft) above the elevation of Texas Springs (six separate ground-water seeps). However, the existing monitoring well will provide a valuable check on any local water-level changes induced by pumping. 


\section{REFERENCES}

Barbier, M.G., 1983, The Mini-Sosie method: Boston, Mass., International Human Resources Development Corp., p. 1-86.

Hunt, C.B., and Mabey, D.R., 1966, Stratigraphy and Structure of Death Valley, California: U.S. Geological Survey Professional Paper 494-A, 162 p., 3 plates (plate 1, 1:96,000 scale).

Klinger, R.E., 1998, Active folding and faulting in the Texas Spring syncline [Day 2, Stop 5 of a field tour, Death Valley National Monument], in Interconnectivity and relationships between soil science, geomorphology, geology, and paleoclimatology: PSSAC 1998 Annual Meeting, Death Valley, California, March 5-8, p. 106-111.

Klinger, R.E., and Piety, L.A., 1996, Evaluation and characterization of Quaternary faulting on the Death Valley and Furnace Creek faults, Death Valley, California: Yucca Mountain Project Activity 8.3.1.17.4.3.2, Seismotectonics Report 96-10, Seismotectonics and Geophysics Section, U.S. Bureau of Reclamation, Technical Service Center, Denver, Colorado, 98 p.

Klinger, R.E., and Piety, L.A., 1999a, Late Quaternary flexural-slip folding and faulting in the Texas Springs syncline, Death Valley National Park, in Slate, Janet, ed., The Status of Geologic Research and Mapping in Death Valley National Park, Conference Proceedings Volume, April 9-11, 1999, Las Vegas, Nevada: U.S. Geological Survey Open-File Report 99153, p. 159-161.

Klinger, R.E., and Piety, L.A., 1999b, Texas Springs syncline and Echo Canyon thrust [Stop 4], in Slate, Janet, ed., The Status of Geologic Research and Mapping in Death Valley National Park, Conference Proceedings Volume, April 9-11, 1999, Las Vegas, Nevada: U.S. Geological Survey Open-File Report 99-153, p. 172-174.

Kunkel, F., 1959, Report on exploratory drilling at Death Valley National Monument, Inyo Country, California: U.S. Geological Survey Administrative Report, prepared at the request of the National Park Service, Department of the Interior, 15 p., 2 plates.

Machette, M.N., Ninci Martinez, Carlos, Crone, A.J., Haller, K.M., and D'Addezio, Giuliana, 1999, Geologic and seismic-hazard investigations of the Cow Creek area, Death Valley National Park, California: U.S. Geological Survey Open-File Report 99-155, 42 p., 17 figures, 2 appendices, 2 plates.

McAllister, J.F., 1970, Geology of the Furnace Creek borate area, Death Valley, Inyo County, California: Sacramento, California Department of Conservation, Division of Mines and Geology Map Sheet 14, scale 1:24,000, with 9 p. text.

Wright, L.A., Greene, R.C., Cemen, I., Johnson, F.C., and Prave, A.R., 1999, Tectonostratigraphic development of the Miocene-Pliocene Furnace Creek Basin and related features, Death Valley region, California, in Wright, L.A., and Troxel, B.W., eds., Cenozoic Basins of the Death Valley Region: Geological Society of America Special Paper 333, p. 87-114.

Yilmaz, O., 1987, Investigations in Geophysics, no.2, Seismic Data Processing: Tulsa, Okla., Society of Exploration Geophysicists, 526 p. 